\title{
Working
}

\section{The Stock Market and Cross-Country Differences in Relative Prices}

\author{
Borja Larrain
}

\begin{abstract}
:
This paper studies the impact of stock market development on cross-country relative prices (the real exchange rate). A nonlinear relationship is uncovered in the cross-section: prices and the stock market increase together in the beginning; then prices fall as the stock market continues to develop. In fact, among rich countries the relationship between prices and the stock market is negative. This result obtains after controlling for per capita income and for endogeneity issues by using legal origins. A small-open-economy model is presented to explain the connection between stock market development and relative prices: better investment opportunities increase consumption levels and the price of nontradable goods (income effect); but if stock market assets are less labor-intensive than previous entrepreneurial technologies, prices can fall as the stock market grows because more labor is available for producing nontradables (substitution effect). This paper illustrates the connection of the stock market with goods and labor markets; it also has potential implications for the political economy of financial development. In a sideline contribution, it provides prices for entrepreneurial assets.
\end{abstract}

JEL Codes: F3, G0

Borja Larrain is an Economist at the Federal Reserve Bank of Boston. His email address is borja.larrain@bos.frb.org.

This paper, which may be revised, is available on the web site of the Federal Reserve Bank of Boston at http://www.bos.frb.org/economic/wp/index.htm.

The views expressed in this paper are solely those of the author and do not reflect official positions of the Federal Reserve Bank of Boston or the Board of Governors of the Federal Reserve System.

I thank Mark Aguiar, Chris Foote, Dick Kopcke, Miklós Koren, Suzanne Lorant, Geoff Tootell, Paul Willen and seminar participants at Harvard University and the Boston Fed for comments. I especially thank John Campbell for many suggestions in the early stages of this project. All errors are mine.

This version: January 2005. 


\section{Introduction}

The fact that finance can affect real activity is well established by now. For instance, Levine (2004) concludes that the financial development of a country exerts a positive influence on macroeconomic growth. At the micro level, the modern literature on corporate finance and investment shows that the irrelevance theorem of Modigliani and Miller fails to hold in practice (see Stein (2003) for a recent survey). In general, the evidence shows that financial arrangements are an important driving force of many real-side phenomena, and not just a companion or by-product of the real economy.

This paper explores the connection between finance and yet another realside variable: relative prices. In particular, it explores how stock market development affects the ratio of price levels across countries, also known as the real exchange rate. The real exchange rate between two countries is the relative cost of a basket of goods expressed in a common numeraire. It is standard to explain the variation in the real exchange rate by variations in the relative price of nontradable goods (that is, how much of the tradable good do we need to forego in order to buy one unit of the nontradable good). The paper shows that the development of the stock market affects real exchange rates, and the model tracks those changes down to the relative price of nontradables.

The importance of relative prices cannot be stressed enough. As Obstfeld and Rogoff (1996, p. 199) put it: "... International relative prices have long been at the heart of open-economy analysis." For example, the real exchange rate is a key variable for making comparisons of the cost of living in different countries, and for determining the current account balance.

Even from the pure perspective of finance, finding an effect of the stock market on relative prices can have important repercussions. As in most models, the price of nontradables in this paper is closely related to the wage earned by workers. If the stock market affects wages, then it affects the welfare of workers and potentially the political equilibrium of the country. For example, if higher stock market development lowers wages (that is, workers are able to buy less of the tradable good), we can expect workers to oppose its development. Despite the fact that these political economy implications go beyond the scope of this paper, it is important to keep them in mind when asking why small financial systems fail to develop. The simple answer

might be that it is not to everyone's advantage, as pointed out by Rajan and Zingales (2003). 
Empirically, the findings show that there is a nonlinear relationship between prices and the development of the stock market. In the beginning, prices rise as the stock market grows, but after some point prices start to fall. This result controls for the level of income of the country, other determinants of price levels such as government expenditures, and, most importantly for the endogeneity of stock market development. As proposed by La Porta et al. (1997, 1998), the legal origin of the country is used as an instrument.

Though the results are robust and imply the causality running from the stock market to relative prices, they also beg for an explanation. It is not at all obvious that there should be a relationship, much less a non-linear relationship, between these two variables. The model in this paper provides a stylized explanation for this effect.

The model examines what can be interpreted as the transition from an economy based on private entrepreneurship to a stock market economy. Rajan and Zingales (1998) first noted that the development of the stock market has an asymmetric effect on different sectors in the economy; in particular, some sectors grow faster than others as the stock market develops. Svaleryd and Vlachos (2005) show the same effect in levels rather than growth rates, implying that countries with larger stock markets specialize in some sectors. The model assumes that these sectors are more capital-intensive as a simple way to capture the characteristic that identifies the technologies more prone to use the stock market. Since stock markets allow firms to raise large amounts of financial capital, it is intuitive to think that capitalintensive sectors benefit the most, because, for example, they require greater upfront investment in plant and equipment than do labor-intensive sectors. In other words, stock market development is a comparative advantage for capital-intensive technologies.

In the terminology of the model, stock market assets (or the technologies underlying these assets) are more capital-intensive than entrepreneurial assets. This paper studies what happens to the relative price of nontradable goods (wages) as capital is shifted from entrepreneurial assets to stock market assets. There are two opposing effects, the income effect and the substitution effect. The income effect comes from the fact that investing in assets with higher returns in a more diversified portfolio increases consumption growth. This point is made by Obstfeld (1994) in the context of international financial integration. The growth of consumption pushes up the demand for nontradable goods and therefore the relative price. The countervailing substitution effect tends to lower wages. The shift towards less labor-intensive technolo- 
gies makes more labor available for use in the production of nontradables and puts downward pressure on prices and wages.

The natural interpretation of the empirical evidence is that the income effect dominates in the beginning as the stock market develops, and later on the substitution effect sets in. The model illustrates these two effects and the conditions under which we might expect the income or the substitution effect to dominate. For example, the correlation between the entrepreneurial asset and the stock market is a key parameter. When the correlation between the two is high, an increase in the stock market of $\mathrm{x}$ percent implies a larger reduction in entrepreneurial investments because of hedging considerations. This makes the substitution effect stronger and probably dominant. We can imagine the correlation being high in a country where the stock market is big - a stock market that covers a wide spectrum of activities and risks, and consequently where the entrepreneurial assets are highly correlated with assets already in the market. In some sense, a bigger stock market implies that the risk-taking capacity of investors is already used, discouraging the entrepreneurial investments that are more closely related to labor, and driving down wages.

The model puts the classical portfolio approach of Merton (1969, 1971) into the framework of a small open economy with a representative entrepreneur (the owner of capital). Capital can be allocated to two classes of risky assets: the stock market and private entrepreneurship. One further difference between the two assets is that the entrepreneurial asset is not traded (that is, it is held only by local entrepreneurs) and therefore its return is determined within the local economy. The return on the stock market - the tradable asset - is determined in a global market and therefore is a given to the entrepreneur. The entrepreneur shifts his portfolio among these asset classes according to his risk preferences and the risk-return trade-offs that the assets offer. The allocation of wealth in turn determines consumption and the relative price of goods (or the wage).

This paper contributes mainly to the literature on the real effects of finance, in this case the impact of financial development on relative (real) prices. The previous literature shows the cross-sectoral implications of financial development on output. The results concerning prices in this paper are a natural reflection of the previous findings about quantities. Moreover, the fact that financial markets affect real prices opens an explicit channel through which the effects of finance can be traced to labor and goods markets. 
Also, to the extent of my knowledge, the finding that financial development is an important determinant of the real exchange rate has not been noted before. This connection can have important implications for issues in international economics such as the study of the current account. For instance, the recent debate about the sustainability of the current account position in the United States underscores the need for a fall in the relative price of nontradables to move the current account back into balance (Obstfeld and Rogoff (2004)). One unorthodox policy recommendation that emerges from this paper is that increasing stock market participation could help to achieve the real depreciation that is needed.

A sideline contribution of this paper is obtaining prices for entrepreneurial assets. In their study of entrepreneurial wealth in the United States, Moskowitz and Vissing-Jørgensen (2002) note that there is a lack of theoretical work in this area. The biggest obstacle - in theory and in practice -is that entrepreneurial assets are not traded and therefore returns are unobservable. This paper provides a simple way to obtain the returns on these assets by linking them directly to the real exchange rate, which is observable.

The rest of the paper is organized as follows. Section 2 presents empirical evidence on the relation between the stock market and cross-country differences in price levels. Section 3 describes the portfolio model, characterizes the equilibrium of the small open economy, and shows how the empirical results can be interpreted. Section 4 concludes.

\section{The Stock Market and Cross-Country Dif- ferences in Price Levels}

The main result of this section is that cross-country differences in price levels reflect not only a country's relative wealth, but also how much wealth is allocated to the stock market. In fact, even among countries of very similar income, we observe that the allocation of wealth has a significant effect on price levels. The size of the stock market has explanatory power over and above that of other variables suggested by the literature and even after taking care of endogeneity issues. The relation between the stock market and prices is nonlinear; they rise together in the beginning, and then prices fall as the stock market continues to grow. For surveys of the real exchange rate literature and the related PPP literature, see Froot and Rogoff (1995), Rogoff 
(1996), and Taylor and Taylor (2004).

\subsection{Empirical Model and Data}

The basic regression is

$$
\begin{aligned}
& \log \left(\frac{p_{j}}{p_{u . s .}}\right)=\alpha_{0}+\alpha_{1}\left(\frac{{\text { Stock } \text { Market }_{j}}_{G D P_{j}}}{G D \alpha_{2}}\left(\frac{{\text { Stock } \text { Market }_{j}}^{2}}{G D P_{j}}\right)^{2}\right. \\
& +\alpha_{3} \log \left(\frac{y_{j}}{y_{u . s .}}\right)+\epsilon_{j} \text {. }
\end{aligned}
$$

The dependent variable is the price level in country $j$ relative to the price level in the United States. This ratio shows the cost in dollars of a reference basket of consumption goods in country $j$ relative to its cost in the U.S. Prices are taken from the Penn World Table (PWT version 6.1), which updates the work of Summers and Heston (1991) on international comparisons. These price levels capture the within-country (or across-goods) and the between-country variation in relative prices at a point in time. As noted by Summers and Heston, a major source of variation in relative prices comes from nontradable goods (see their Table I). Standard price indexes cannot be used for this purpose since cross-sectional differences have no interpretation; only changes in standard price levels can be compared across countries. ${ }^{1}$ Another advantage of the PWT is that it refers to the same basket of identical, quality-adjusted goods across countries. The stock market capitalization over GDP is taken from Beck, Demirgüç-Kunt, and Levine (1999). The per capita income of country $j$ relative to the U.S. $\left(\frac{y_{j}}{y_{u . s .}}\right)$ is also from the PWT.

Regression (1) is a cross-section of 82 countries in the year 1995. The sample consists of the intersection of the PWT and the database of Beck, Demirgüç-Kunt, and Levine (1999) for the year 1995. The data are shown in the appendix. When we add other covariates to the regression, we lose some countries because of data availability.

A log specification is used for the price level and income, as is standard in the literature. In terms of the stock market, a quadratic term is used to

\footnotetext{
${ }^{1}$ Changes in standard price levels can be compared across countries, but that is not sufficient for the purposes of this paper. Changes in prices must be matched with changes in the independent variables, such as the stock market; and our instruments explain the level of the stock market, but not necessarily changes over time.
} 
capture any possible non-linearity. All results still hold up with the stock market in logs instead of via the quadratic term. Both specifications capture the same non-linearity, but it is easier to interpret the variation in $\alpha_{1}$ across sub-samples using the quadratic specification (a log specification implies that the slope tends to zero, not that it changes signs from positive to negative).

Per capita income is treated as exogenous, also following the literature. Income captures three main determinants of national price levels: productivity differentials or the Balassa-Samuelson hypothesis, differences in endowments of capital and labor (Bhagwati (1984)), and nonhomothetic tastes for nontradable goods (Bergstrand (1991)). Data constraints limit the possibility of measuring these three channels directly for a large cross-section of countries.

The development of the stock market is treated as an endogenous variable. In IV regressions, the origin of the country's law (La Porta et al. (1998)) is used as instrument for the stock market. Legal families are largely determined by colonial history, making it hard to argue against their exogeneity. Moreover, in addition to standard economic variables, they are important factors in explaining a country's stock market size, as seen in the first-stage F-statistics reported throughout the paper. The five legal families considered are: English, French, German, Scandinavian, and Socialist. ${ }^{2}$ The fact that we have instruments is critical. Otherwise, we would not be able to say much from the correlation of two endogenous variables such as the real exchange rate and stock market capitalization. The simultaneous determination of the two variables is evident from the model in Section 3.

The regression in (1) is also run including other variables suggested by theories of the real exchange rate: government expenditures, the accumulated current account balance, the terms of trade, and GDP growth (another proxy for the Balassa-Samuelson effect). ${ }^{3} \quad$ Adding these covariates does not change the main results.

\footnotetext{
${ }^{2}$ The most comprehensive list of countries and their legal origin is in La Porta et al. (1999).

${ }^{3}$ The other covariates are: accumulated current account balance as a percentage of GDP from 1990 to 1995; government expenditures over GDP in 1995; the average change in the terms of trade from 1990 to 1995; and average GDP growth from 1990 to 1995. The current account is taken from the IFS. Goverment expenditures are from the IMF Government Financial Statistics. Terms of trade are from the Global Development Finance \& World Development Indicators. GDP is from the Penn World Table 6.1 (rgdpch).
} 


\subsection{Results}

The basic result is displayed in Table 1 . Columns 1 through 4 show the regressions that use only the stock market capitalization and its quadratic term as independent variables. We find a positive coefficient on the stock market, but a negative coefficient on the quadratic term. The relative magnitudes of $\alpha_{1}$ and $\alpha_{2}$ imply that the stock market reduces prices only after it surpasses high levels of capitalization (around 1.5 times GDP). Both coefficients are highly significant and are even larger in the IV regressions. Figure 1 illustrates the non-linear relationship between the stock market and price levels.

The stock market coefficients survive the inclusion of the country's relative income in columns 8 and 9, although the magnitudes are reduced. From the median stock market capitalization in the sample -20 percent of GDPan increase in capitalization of 1 percent of GDP would increase prices by about 2.5 percent (equivalently, an appreciation of the real exchange rate of 2.5 percent). An increase of 1 percent in income would increase prices by about 0.4 percent- 0.5 percent; this is in line with previous estimates in the literature.

In order to see more clearly the nonlinear relation, in Table 2 we split the sample into three, according to the size of the stock market. We see that in countries with relatively small stock markets, an increase in capitalization increases prices. The large coefficient in the IV estimation comes from the fact that a 1 percent of GDP increase in capitalization is a big change for these countries. The relationship between prices and the stock market is flat in the group with a medium-size stock market. Finally, in the group of big stock markets, we observe a negative and significant coefficient. This explains why the quadratic term in Table 1 is so important. The same pattern is seen if we split the sample according to per capita income, as in the lower panel of Table 2. The correlation of the stock market with income is relatively high (0.38); nevertheless, sorting by stock market size and income are not exactly the same. For example, Iceland is in the group with small stock markets, but among rich countries. On the other hand, countries such as Malaysia or South Africa, with big stock markets, are only in the middle-income group. Finally, note that the coefficient on income is positive throughout all samples.

Figure 2 shows what is going on in rich countries. The figure plots the OLS residual of the regression of prices on income on the y-axis against 
the stock market capitalization on the x-axis. This can be understood as plotting prices net of the effect of income. We see the negative slope that corresponds to the OLS regression in Table 2 for rich countries. The strength of the instruments can be seen in Figure 2.2, which repeats Figure 2.1, now showing countries by their legal origin. Most of the countries of English origin, such as Australia, Singapore, or the United States, lie below the OLS line. Out of 12 countries below the fitted line, 8 are of English origin. On the other hand, countries of French, German, or Scandinavian origin, which have less-developed stock markets, lie mostly above the line. This explains why the instrumented stock market gives an even larger negative coefficient.

Figure 3 shows the differences between rich and poor countries. It presents the average income and price level for rich and poor countries, by legal origin. Keep in mind that countries of English origin tend to have more-developed stock markets. Among rich countries, income per capita is about 10 percent higher for French-origin countries compared with Englishorigin countries, but French-origin countries have 30 percent higher prices. Therefore, even after controlling for income differences, it is easy to see why the coefficient on the stock market (or the fraction instrumented by legal origin) is negative among rich countries. Among poor countries, the situation is quite different. Prices are almost the same, but the income of countries of English origin is much lower. Thus, even with lower income, prices are as high as in French-origin countries, which explains why stock market capitalization increases prices in this group.

Tables 3 and 4 display several robustness checks. Table 3 adds to the basic specification some variables that are frequently considered to be determinants of price levels. For example, government expenditure can increase prices if it is tilted towards nontradable goods. A similar argument applies to accumulated current account deficits if foreign preferences differ from domestic preferences (the "transfer" problem; see Lane and Milesi-Ferretti (2004)). ${ }^{4}$ Finally, the terms of trade and GDP growth - another proxy for the BalassaSamuelson effect - are sometimes included in empirical studies of price levels. None of these variables has an impact on the results; in fact, they are never

\footnotetext{
${ }^{4}$ The correlation between the accumulated current acount balance computed here and what Lane and Milesi-Ferretti (2001) call CUMCA is 0.68. They perform a much more careful analysis of the net foreign asset position of a country, but for the same reason they end up with fewer countries than are presented here. Using the Lane and Milesi-Ferretti measure does not change the results. The measure in Kraay et al. (2000) is also available for fewer countries.
} 
significant.

Table 4 addresses a different question. The IV regression assumes that legal origins have no effect on price levels except through the stock market. But recent studies show that legal origins are correlated with laws beyond those affecting the development of the stock market - in particular, the laws regulating the entry of new firms (Djankov et al. (2002)) and the regulation of labor (Botero et al. (2004)). It is also possible that these other channels affect prices. For instance, tighter labor regulation can increase wages and therefore prices. $^{5}$ The relevance of regulation is tested using the number of procedures required, an indicator of how cumbersome it is to start a new business, and an index for labor law. ${ }^{6}$ In the IV regression these variables are treated as endogenous and they are instrumented using legal origins. Despite the theoretical appeal of these variables, they are not relevant in explaining price levels as seen in table 4 . In fact, the results show clearly that the effect of legal origin comes via the stock market and not through these other channels.

Overall, the results suggest that the allocation of wealth has an effect on relative prices through a distinct channel, separate from the effect of income. The IV regressions show that the causality runs from the stock market to prices. The non-linear relationship is also hard to reconcile with pre-existing theories of the real exchange rate. The next section develops a model to interpret these results, and, in particular, the reversal in the effect when going from poor to rich countries.

\section{A Portfolio Model of Price Levels}

The purpose of the model is to illustrate more formally the substitution and income effects mentioned in the introduction. The model describes a mechanism, conditional on some important assumptions. To some extent, the real effects of finance are embedded in the model rather than derived; the model explains the how, not so much the why. Nevertheless, the model allows us to see the effects of relevant parameters, which is not simple to do

\footnotetext{
${ }^{5}$ See Blanchard and Giavazzi (2003) for a careful analysis of the effects of regulation in goods and labor markets on wages and prices.

${ }^{6}$ The number of procedures is taken from Djankov et al. (2002). The labor law index is the average of the employment laws index, the collective relations laws index, and the social security laws index in Botero et al. (2004).
} 
using pure intuition.

The model captures the reallocation of labor and changes in the consumption of various goods that are produced by shifts in the portfolio of a representative investor. Different assets operate with different underlying technologies, and, therefore, the shifts from one asset to another cause changes in the real economy. The model tracks down these effects in a simple way and explains under what circumstances it is reasonable to expect the patterns observed in the data.

Most assumptions in the model are standard, for instance, CRRA preferences, constant returns to scale, nontradable goods are more labor-intensive than tradable goods, and so on. ${ }^{7}$ The model features two assumptions that require further explanation.

The key assumption is that assets traded in the stock market operate with more capital-intensive technologies than do entrepreneurial assets. This assumption is necessary for the model to deliver a non-linear relationship between prices and the stock market. If stock market assets are more labor intensive than entrepreneurial assets, then the model can only generate an upward slope in prices if the stock market grows. A formal justification of this assumption is beyond the scope of this paper, although the recent literature on financial development provides support for it.

Starting with the seminal paper of Rajan and Zingales (1998), the literature on financial development shows that some sectors grow disproportionately as the stock market develops. In particular, the industrial composition of a country becomes specialized in sectors that are more intensive in capital and skilled labor (Carlin and Mayer (2003), Svaleryd and Vlachos (2005)). ${ }^{8}$ Some examples of these sectors (within manufacturing) include producers of machinery, professional equipment, and pharmaceuticals. ${ }^{9}$ This implies that some activities are better suited for the stock market, or in more need for the mechanisms of control and information provided by stock markets. Another way to put this is that reducing financial frictions constitutes a comparative advantage for capital-intensive sectors. Therefore, these sectors develop

\footnotetext{
${ }^{7}$ The classic reference for continuous-time general equilibrium models is Cox, Ingersoll, and Ross (1985). For extensions with multiple goods and multiple production factors see Richard and Sundaresan (1981) and Sundaresan (1984).

${ }^{8}$ This implies that labor in the model is better interpreted as unskilled labor, which is more utilized in services.

${ }^{9}$ For the equity-dependent sectors, see the NBER working paper version of Rajan and Zingales (1998).
} 
more as frictions are reduced. Our assumption that stock market assets are more capital intensive can be considered as a reduced form of this recent evidence that links the stock market and the type of activities associated with it.

A second important assumption, which makes the model tractable, is that the supply of labor is inelastic and proportional to the stock of wealth of the economy. This makes the ratio of labor to capital a constant (not necessarily equal to one, though). From the technical point of view, this assumption simplifies the model by making all variables scalable by total wealth.

An important consequence of this assumption is that, in the model, prices do not vary with the level of wealth. This may not be a bad thing; in practice, wealth is much more volatile than prices (Brandt, Cochrane, and Santa-Clara (2004)). Since prices are wealth-independent, the model can be understood as focusing on the pure effect of wealth allocation. From the empirical evidence, we know that there are differences in prices between countries of the same wealth or income, or when we control for income, and the model explains why.

Finally, this second assumption is analogous to the need for labor-augmenting technical progress in growth models. There is no well-defined steady state without this assumption, and something similar is the case in this model. Basically, the sectors that use labor will eventually disappear if the endowment of labor does not increase.

After presenting the model and its main implications, the paper explores the effects of relaxing some assumptions.

\subsection{The economy}

The model is framed in terms of a small open economy with a representative entrepreneur who owns the capital stock. Two types of agents live in this economy, entrepreneurs and workers, and everyone behaves competitively. Labor is a nontradable factor. Workers receive a wage in terms of the traded good and they behave as hand-to-mouth consumers. (Workers have no financial wealth.) The decision to supply labor is exogenous to the model.

At each point in time the representative entrepreneur decides on capital investments and expenditures on the consumption good (traded) and services (nontraded). Services are produced by local workers and can be consumed by local entrepreneurs only. Three assets deliver the consumption good: a riskless bond, the stock market, and the entrepreneurial asset. Foreigners do 
not invest in the entrepreneurial asset, but they invest in the stock market.

\subsubsection{Preferences and endowment}

The representative entrepreneur has preferences at time 0 over future uncertain consumption $(C)$ and services $(S)$. Lifetime utility is additive and time is continuous, making the objective function the following:

$$
E_{0}\left[\int_{0}^{\infty} e^{-\delta t} U(C(t), S(t)) d t\right]
$$

where $E_{0}$ is the expected value operator, conditional on information available at time 0 , and $\delta$ is the subjective discount rate. In the rest of the analysis, the following non-separable intra-period utility function is used:

$$
U(C, S)=\frac{\left(C^{\eta} S^{1-\eta}\right)^{1-\gamma}}{1-\gamma}
$$

The specification in (3) is of the CRRA form, where $\gamma$ is the coefficient of relative risk aversion. Consumption and services are combined using a Cobb-Douglas aggregator, where $\eta$ is the share of the consumption good in total expenditures. In the case of $\gamma=1$, it corresponds to the logarithmic utility function $\eta \log (C)+(1-\eta) \log (S)$.

At time 0 , the entrepreneur is endowed with initial wealth $W(0)$. Wealth is provided in units of the consumption good, which is the numeraire.

\subsubsection{Tradable assets}

A riskless bond $(B)$ and a single risky asset $(M)$ are continuously traded. The risky asset is the portfolio of assets in the stock market. The returns of the assets (in units of the consumption good) follow one-dimensional Ito processes:

$$
\begin{aligned}
\frac{d B}{B} & =r d t \\
\frac{d M}{M} & =\mu_{m} d t+\sigma_{m} d z_{m}
\end{aligned}
$$

Risk is captured by the term $d z_{m}$, which is a standard Brownian motion. Note that the riskfree rate $(r)$, the expected return of the stock market $\left(\mu_{m}\right)$, 
and the standard deviation of the return $\left(\sigma_{m}\right)$ are independent of time, so there are no intertemporal hedging demands in the model.

Short sales of both assets are allowed, and the repayment of short sales is enforceable. The fact that unlimited borrowing and lending is allowed separates this paper from theories that require limited capital mobility or borrowing constraints, such as that of Bhagwati (1984).

The stock market is priced in a global market; therefore, the local entrepreneur faces a given return. The assumption in the paper is that the local stock market is perfectly integrated, implying a flat demand for these assets. Foreign arbitrageurs are willing to buy and sell infinite amounts if the price deviates from its equilibrium in the global market.

We refer to $M$ as the local stock market to draw a comparison with the previous empirical results. But this is not absolutely necessary. $M$ could represent the world market portfolio. In such case, a shift to this asset would be a capital flight, a phenomenon that we explore in the caveats section. The widespread home-bias in portfolios (French and Poterba (1991)) is a justification for considering the entrepreneur as shifting funds only from the local stock market to the entrepreneurial asset and back. The model with $M$ as the local stock market is more directly applicable to the empirical evidence.

The stock market requires capital, but not labor. This is an extreme case of the assumption that stock market assets are less labor-intensive than entrepreneurial assets. This assumption can be modified without affecting the results if we preserve the relative labor intensities of the assets (see the caveats section).

\subsubsection{The entrepreneurial asset}

The entrepreneurial asset has three important characteristics. First, it requires two inputs, labor $(L)$ and capital $(K)$, which is measured in units of the consumption good. Second, both inputs are in limited supply: there is a given number of local workers and the supply of capital is limited to local entrepreneurs. And third, the risks involved in the entrepreneurial asset cannot be perfectly hedged with the stock market.

Only local entrepreneurs can invest in this asset, and therefore the equilibrium return is determined within the local economy. An underlying agency problem (not explicitly modelled) makes the asset nontradable. ${ }^{10}$ A more

\footnotetext{
${ }^{10}$ The model assumes that the agency problem is severe enough so that not even a
} 
positive way of seeing the nontradability is to think of the entrepreneur as receiving access to a technology that nobody else can use. Access to the stock market, on the contrary, is freely available to everybody.

$L$ and $K$ are restricted to be positive. Note that the restriction $K \leqslant W$ is not imposed, in fact, $K$ can be larger than $W$ if the entrepreneur makes short sales of tradable assets and invests in the entrepreneurial technology.

The instantaneous flow of the consumption good produced by the entrepreneurial asset is

$$
d Y=\mu_{y} L^{\nu} K^{1-\nu} d t+\sigma_{y} K d z_{y}
$$

The expected flow has a Cobb-Douglas form, making (5) a stochastic, constant-returns-to-scale technology. $d z_{y}$ represents a standard Brownian motion, and $\operatorname{corr}\left(d z_{m}, d z_{y}\right) \equiv \rho$. Assuming $-1<\rho<1$ implies that the entrepreneurial risk cannot be perfectly hedged. It is useful to rewrite (5) in the form of return to capital (gross of labor payments) ${ }^{11}$

$$
\frac{d Y}{K}=\mu_{y}\left(\frac{L}{K}\right)^{\nu} d t+\sigma_{y} d z_{y} .
$$

Equation (6) shows that the entrepreneur sets the expected return by picking the capital-labor ratio. The variance of the return, however, is constant. The entrepreneur faces diminishing marginal returns to investment in this asset, but on the tradable assets he faces constant returns.

One important feature of the entrepreneurial asset is that it produces a tradable good. In this sense, it is a perfect substitute for assets available in the market. Some might expect a nontradable asset to produce a nontradable good, but this is not necessarily the case. The nontradabilities operate at different levels. In goods markets, nontradability is a consequence of transportation costs. In asset markets, it is a consequence of frictions, such as agency or asymmetric information, that prevent the entrepreneur from selling claims on the flows produced by the asset. In order to stress the difference between the two concepts, the entrepreneurial asset produces a tradable good in the model.

small percentage of the local asset is tradable. This assumption avoids the complication of computing the price of the asset to foreign investors and incorporating that into the entrepreneur's wealth.

${ }^{11}$ Since the entrepreneurial asset does not have a price, the return on this asset consists only of dividends. There are no capital gains in a nontradable asset. 


\subsubsection{The labor market}

Services are produced with local labor on a one-to-one basis. Since services are nontradable goods, it is standard to assume that they are more laborintensive than tradable goods. To simplify things, we assume that only labor is used in their production. The total demand for labor is then $L+S$ since the only users of labor are local entrepreneurs.

The supply of labor is assumed to be inelastic, but proportional to wealth: $\theta W$. The parameter $\theta$ is the labor-capital ratio of the economy. This assumption can be understood as representing a reduced form for technical progress in the utilization of factors or some externality like learning by doing (that is, richer countries make better use of their resources). In the case of technical progress, $\theta$ would be the number of workers and $\theta W$ the efficiency units of labor. Technical progress in labor is necessary for balanced growth, since hours worked per person show no trend over time (King and Rebelo (1999)). On a practical level, this assumption simplifies the problem significantly by making all variables scalable by wealth. The entrepreneur's problem has a second state variable (the price level) if this assumption is modified, which makes the problem intractable.

If we normalize labor demand by wealth, $l \equiv \frac{L}{W}$ and $s \equiv \frac{S}{W}$, then the following equation shows the market-clearing condition for the labor market:

$$
l+s=\theta
$$

From (7) we identify $p^{*}$, the equilibrium price of services (or wage) in terms of the consumption good. Entrepreneurs and workers are assumed to behave as price takers.

The table below summarizes the productive structure of the economy

\begin{tabular}{l|llll} 
Sector & Good Produced & Factors & & $\begin{array}{l}\text { Return } \\
\text { Capital }\end{array}$ \\
& & Labor & on Capital \\
\hline Stock Market & Consumption & yes & no & exogenous \\
Entrepreneurial Asset & Consumption & yes & yes & endogenous \\
Services & Services & no & yes & -
\end{tabular}

This economy illustrates the income and substitution effects in a transparent way. The shift between the stock market and the entrepreneurial asset captures the substitution effect: if more capital is allocated to the stock 
market, then - ceteris paribus - the capital-labor ratio in the entrepreneurial asset is lower, driving down the marginal product (and wages) of labor. On the other hand, in the services sector, labor has an alternative use that does not require capital. Since services accompany consumption in the utility function, their demand depends on consumption growth, which is ultimately linked to the return on investments. This second channel illustrates the income effect. The next section characterizes the equilibrium and shows the interplay of these effects with some comparative statics.

\subsection{Characterization of the equilibrium}

The optimization problem of the entrepreneur consists in choosing the paths for consumption, services, labor, and portfolio allocations so as to maximize (2), subject to the dynamic budget constraint and a given level of wealth (the state variable). ${ }^{12}$ The equilibrium in the local economy is obtained by imposing the market-clearing condition in (7). Let $x$ be the percentage of wealth allocated to the stock market and $k$ the percentage invested in the entrepreneurial asset $(K \equiv k W)$. The change in wealth during an interval $d t$ is

$$
d W=(1-x-k) W \frac{d B}{B}+x W \frac{d M}{M}+d Y-p L d t-p S d t-C d t
$$

The change in wealth consists of the returns on the tradable assets (the first two terms in (8)) plus the income flow from the entrepreneurial asset, less the payments to labor, services, and consumption. Using equations (4) and (5) the budget constraint can be rewritten as

$$
\begin{aligned}
d W= & {\left[r(1-k) W+\left(\mu_{m}-r\right) x W+\mu_{y} L^{\nu}(k W)^{1-\nu}-p L-p S-C\right] d t } \\
& +x W \sigma_{m} d z_{m}+k W \sigma_{y} d z_{y} .
\end{aligned}
$$

Let $J(W, t)$ denote the value function for the entrepreneur's problem. The Bellman equation for this problem is then

\footnotetext{
${ }^{12}$ The retrictions $K \geqslant 0, L \geqslant 0, C \geqslant 0$, and $S \geqslant 0$ are ignored in the rest of the analysis. The results are not influenced by these constraints for a wide range of parameters, as shown in the examples.
} 


$$
0=\max _{\{C, S, L, k, x\}}\left\{e^{-\delta t} U(C(t), S(t))+E d J(W, t)\right\} .
$$

In the case of infinite horizon, the value function is of the form $J(W, t)=$ $e^{-\delta t} I(W)$, which corresponds to the stationary solution. Using Ito's lemma we can rewrite (10) as

$$
\begin{gathered}
\delta I=\max \left\{\frac{\left(C^{\eta} S^{1-\eta}\right)^{1-\gamma}}{1-\gamma}+I_{W}\left[r(1-k) W+\left(\mu_{m}-r\right) x W\right.\right. \\
\left.+\mu_{y} L^{\nu}(k W)^{1-\nu}-p L-p S-C\right] \\
\left.+\frac{1}{2} I_{W W} W^{2}\left[x^{2} \sigma_{m}^{2}+2 x k \rho \sigma_{m} \sigma_{y}+k^{2} \sigma_{y}^{2}\right]\right\} .
\end{gathered}
$$

Proposition 1 characterizes the optimal portfolio choice and the equilibrium in the local economy.

Proposition 1 Let $p^{*}$ be the equilibrium price of nontradables. The value function for the entrepreneur's optimization problem is of the form

$$
I(W)=\Psi\left(p^{*}\right)^{-\gamma} \frac{W^{1-\gamma}}{1-\gamma} .
$$

Defining

$$
\mu_{k} \equiv \mu_{y}(1-\nu)\left(\frac{\mu_{y} \nu}{p^{*}}\right)^{\frac{\nu}{1-\nu}}
$$

and $\beta \equiv \frac{\rho \sigma_{y}}{\sigma_{m}}$, then the optimal expenditure in consumption and services and the optimal allocations of capital and labor are

$$
\begin{aligned}
C^{*} & =\Psi\left(p^{*}\right) W \eta^{\frac{1}{\gamma}}\left[\frac{1-\eta}{\eta p^{*}}\right]^{\frac{(1-\gamma)(1-\eta)}{\gamma}} \\
S^{*} & =\Psi\left(p^{*}\right) W \eta^{\frac{1}{\gamma}}\left[\frac{1-\eta}{\eta p^{*}}\right]^{\frac{1-\eta(1-\gamma)}{\gamma}} \\
k^{*} & =\frac{1}{\gamma}\left[\frac{\mu_{k}-r-\beta\left(\mu_{m}-r\right)}{\left(1-\rho^{2}\right) \sigma_{y}^{2}}\right] \\
x^{*} & =\frac{1}{\gamma}\left(\frac{\mu_{m}-r}{\sigma_{m}^{2}}\right)-\beta k^{*}
\end{aligned}
$$




$$
L^{*}=\left(\frac{\mu_{y} \nu}{p^{*}}\right)^{\frac{1}{1-\nu}} W k^{*} .
$$

The equilibrium price $p^{*}$ is determined by the market clearing condition

$$
l^{*}+s^{*}=\theta \text {. }
$$

Proof. By substitution. $\Psi\left(p^{*}\right)$ is given in the appendix.

The portfolio allocations in (16) and (17) have an intuitive interpretation. The first term in (17) corresponds to the myopic demand for a risky asset, basically the Sharpe ratio divided by the standard deviation times the risk-aversion coefficient. The second term is a hedging demand. The entrepreneur reduces his holdings of the risky asset (or sells short) in order to avoid being hit in the stock market and the entrepreneurial investment at the same time. The parameter $\beta$ governs the magnitude of the hedging demand. In the case of $\beta=0$, the hedging demand is zero since both investments are uncorrelated and one cannot buy insurance by reducing the exposure to the market risk. $\quad \beta$ is the weight of the market in the hedging portfolio, that is, the portfolio of tradable assets that is maximally correlated with the entrepreneurial asset.

The interpretation of $k^{*}$ relies on a Sharpe ratio as well. First, note that $\mu_{k}$ is the expected return of entrepreneurial capital (net of labor payments) at the equilibrium price. ${ }^{13}$ The term $r+\beta\left(\mu_{m}-r\right)$ is the return of the hedging portfolio or the cost of hedging, since the entrepreneur sells short a portfolio of risky assets and bonds with this expected return. The term $\left(1-\rho^{2}\right) \sigma_{y}^{2}$ corresponds to the unhedgeable risk of the entrepreneurial asset. Therefore, optimal investment is proportional to an excess return per unit of unhedgeable risk, or a modified Sharpe ratio. In order to have a positive investment in the entrepreneurial asset, the return on capital must be above the CAPM rate of return $r+\beta\left(\mu_{m}-r\right)$. As can be seen, the CAPM is useful for capital budgeting even for entrepreneurial assets.

In the case in which labor is absent from the model (i.e., $\eta=1, \nu=0$ ), we get $\mu_{k}=\mu_{y}$, and everything reduces to a standard portfolio choice with two risky assets.

\footnotetext{
${ }^{13}$ Alternatively, it is the expected marginal product of capital evaluated at the optimal labor-capital ratio.
} 
A solution that specifies the equilibrium price $p^{*}$ in analytical form is not possible. ${ }^{14}$ Nevertheless, we can say the following about the equilibrium price:

Proposition $2 p^{*}$ is independent of wealth. The equilibrium price depends only on exogenous parameters: preferences $(\gamma, \eta, \delta)$, technology $\left(r, \mu_{m}, \mu_{y}, \sigma_{m}, \sigma_{y}, \rho, \nu\right)$, and the relative factor endowment $(\theta)$.

Proof. By inspection of equation (19).

Since the total demand and supply of labor are homogenous of degree one in wealth, the equilibrium price is homogenous of degree zero. Any shift in demand caused by wealth is perfectly offset by a change in supply. A price that is independent of wealth means that the model can provide an explanation for price differences, even controlling for the wealth of countries. In this sense, this model can complement what is already known about price differences between poor and rich countries.

In this model, the price of the nontradables emerges as a key statistic that summarizes preferences, technologies, and endowments. It is interesting that risk characteristics, like volatility and covariances, are incorporated into the equilibrium price. Other models of the real exchange rate do not include uncertainty in production as a determinant of prices. For instance, in Obstfeld and Rogoff (2000), uncertainty is with respect to monetary policy and tastes.

In equilibrium, $p$ is at the same time the marginal utility of services and the marginal product of labor in the entrepreneurial asset. In this CobbDouglas setting, the marginal utility of services depends on the ratio $C / S$, and the marginal product of labor depends on the ratio $K / L$. By combining equations (14) and (15) we see that the equilibrium price is an increasing function of $C / S$, and from (18) that the price is an increasing function of $K / L$.

Consider for instance an economy with a low $C / S$ ratio, which is to say an economy with many workers in services. This implies - ceteris paribus - a low price, because the marginal utility of services is low. But there is an opposing force, since the presence of many workers in services implies that there are few workers in the entrepreneurial asset, or that the $K / L$ ratio

\footnotetext{
${ }^{14}$ Computationally speaking, though, the system is easy to solve. The intractability of the problem is buried in the market-clearing condition, which is one equation with one unknown.
} 
is high. A high $K / L$ ratio implies a high marginal product of labor and therefore a high wage. The balance of these two forces - which reflect the portfolio decisions of the entrepreneur and the corresponding allocation of workers - determines the price level in equilibrium.

\subsection{Comparative Statics}

This section explores some comparative statics with a numerical example. The baseline parameters and results are reported in Table 5. Higher risk aversion increases the allocation to entrepreneurial assets relative to the stock market, but overall risk-taking falls. In some sense, the entrepreneur seeks to insure consumption by allocating relatively more capital to the entrepreneurial asset. This implies that the substitution effect works in favor of labor, but the income effect works against it. If the entrepreneur takes risk, it is proportionally more in the labor-intensive asset, but the risks taken are too small to increase consumption and the demand for services. As noted by Obstfeld (1994), higher risk aversion implies lower consumption since the agent takes less advantage of high-return assets. The decrease in the consumption of tradables drives down the consumption of services because they are complements in the utility function, and the final effect is to reduce prices. This is almost a pure income effect since substitution is mainly away from the stock market rather than from the entrepreneurial asset (see column $k$ in Table 5).

An interesting exercise, suggested by the previous literature on the real exchange rate, is to vary the relative endowment of labor and capital, $\theta \cdot{ }^{15}$ As labor relative to wealth increases, more capital flows to the entrepreneurial asset due to the scale effect that increases the marginal product in that sector. Wealth in the stock market is therefore reduced. In simple words, countries with abundant labor relative to wealth should have small stock markets. In equilibrium we see that a high labor-capital ratio delivers low prices, which is reminiscent of the Kravis-Lipsey-Bhagwati hypothesis (Bhagwati (1984)). ${ }^{16}$

\footnotetext{
${ }^{15}$ It is tempting to interpret $1 / \theta$ as a proxy for per capita income in the regressions. In fact, Bergstrand (1991) shows that income and capital-labor ratios are strongly associated in the data. But since consumption increases with $\theta$ in the model, this interpretation is flawed. This happens because the owners of capital and labor are separated in the model and adding more workers does not imply lower per capita income or wealth (see the caveats section).

${ }^{16}$ See Obstfeld and Rogoff (1996) for a textbook exposition of the Kravis-Lipsey-
} 
The difference is that capital is not immobile as in that framework; in fact, there are no borrowing constraints here. The only constraint is the risk preference of the entrepreneur.

The last panel of Table 5 shows the effect of $\rho$ - the correlation between the stock market and the entrepreneurial asset. In many respects the results are the same as in a standard portfolio problem with two risky assets. From equation (17) we know that the correlation governs the hedging demand: a lower correlation reduces the hedging demand and increases the allocation to the stock market. A lower correlation also motivates larger investments in the entrepreneurial asset. This happens despite the fact that the entrepreneurial return falls because the cost of funds (the CAPM rate) also falls. In this case, the income and substitution effects go in the same direction when the correlation decreases, and consequently prices increase.

Prices are higher where the entrepreneurial asset is "safer" compared with the stock market: when $\rho$ is low, $\sigma_{m}$ is high, or $\sigma_{y}$ is low (results not shown). In this sense, the price level shows how well endowed a country is in terms of entrepreneurial technologies: countries with relatively safer technologies have higher price levels. On the other hand, high stock-market volatility implies lower prices.

\subsection{Interpretation of Empirical Results}

In the model, the price of nontradable goods is directly related to the domestic price level and therefore to the real exchange rate. If we assume that the law of one price holds for consumption (the tradable good) and that the share of expenditures is the same in the domestic and foreign $(f)$ economies, then the price levels are

$$
\begin{aligned}
P & =(1)^{\eta} p^{1-\eta}=p^{1-\eta} \\
P_{f} & =(1)^{\eta} p_{f}^{1-\eta}=p_{f}^{1-\eta} .
\end{aligned}
$$

The real exchange rate (the ratio of price levels) is simply the ratio of nontradables prices.

$$
R E R=\frac{P}{P_{f}}=\left(\frac{p}{p_{f}}\right)^{1-\eta}
$$

Bhagwati hypothesis. 
The United States is $f$ or the country of reference in the data. The main empirical result to illustrate with the model is how an increase in capitalization can appreciate and depreciate the real exchange rate under different circumstances. The result is obtained from cross-sectional regressions, but it is tempting to think about the time series. For example, consider the cases of Spain and Russia between 1992 and 1997. In those years, the stock market capitalization in Spain rose from 21 percent to 50 percent of GDP, while at the same time the price level fell from 112 to 86 . In Russia, the stock market went from less than 1 percent to 19 percent of GDP, while the price level rose from 15 to 39 . Our model provides a simple explanation for this phenomenon.

The price level and portfolio allocations are endogenous variables, so we need to think of primitive parameters as driving the results. Following La Porta et al. (1997) we interpret the legal origin - the instrument in the empirical part - as showing the differences in the expropriation risk of stock market assets. ${ }^{17}$ In terms of the model, we can think of the net return on the stock market as $\mu_{m}(1-\tau)$, where $\tau$ is an expropriation rate. A lower $\tau$ explains why countries of English origin have bigger stock markets on average. In other words, $\tau$ represents the comparative advantage that countries of English origin have in capital-intensive or stock-market sectors. (Note that $\tau$ does not apply to the return on entrepreneurial assets.)

By varying $\tau$, we can compare countries with stock markets of different sizes. The question that remains is why a change in capitalization (induced by a change in $\tau$ ) can have different effects on the price level. The reason cannot be the level of wealth in the country, since prices in the model are wealth-independent. We focus instead on the correlation of the entrepreneurial asset with the stock market. This correlation governs the hedging demand and therefore the strength of the substitution effect. When the two investments are more correlated, an x percent increase in the stock market is accompanied by a larger decrease in entrepreneurial investment in order to keep risk-taking controlled. And a more pronounced flight of entrepreneurial capital makes the substitution effect stronger. It follows that if $\rho=0$, there is only an income effect.

A high correlation is interpreted as representing what happens among rich countries (big stock markets), and vice versa for a low correlation. In other

\footnotetext{
${ }^{17}$ In La Porta et al. (1997) the expropriation risk is faced by minority investors or non-insiders who do not retain control of their investments.
} 
words, we interpret entrepreneurial opportunities in richer countries as more correlated with tradable assets. Alternatively, entrepreneurial opportunities in poor countries are more novel when compared with what is already in the market. The sheer size of the stock market can be a signal of this correlation, since big stock markets include more industries and risk dimensions than small markets. For example, Morck, Yeung, and Yu (2000) show that stock prices move together more strongly in poor economies than in rich economies, which can be interpreted as a signal that stock markets in rich countries are more diverse.

Table 6 shows the effect of increasing the return on the stock market (or reducing $\tau$ ) in the case of high and low correlations. The increase in $\mu_{m}$ increases stock market capitalization, as can be expected. The substitution effect is stronger in the case of a high correlation, implying that the fall in entrepreneurial activity is larger and the price of services falls. This would be the case in Figure 2 when comparing, for example, the U.S. and France: the U.S. has a bigger stock market and lower prices, even controlling for income. The reverse would be our interpretation for what happens among poor countries: a higher $\mu_{m}$ increases stock market capitalization and prices at the same time. In this case, it is the income effect that dominates.

It is interesting to see what happens in goods markets. Both consumption and services increase as $\mu_{m}$ increases. In the case of a high correlation, more labor is freed from the entrepreneurial asset, but the service sector is not capable of absorbing the extra workers at the old wage. Consequently, the price of services falls by 2 percent, implying a fall in the price level of about 1 percent. The opposite is seen in the case of a low correlation. Here, labor also migrates to the growing service sector, but now services accommodate the new workers, even with a wage increase.

The bottom line is that an exogenous increase in the attractiveness of the stock market has different reallocative effects under different correlation structures. Countries respond to an increased return on the stock market by increasing consumption (as in Obstfeld (1994)), but the implications for the real exchange rate depend on the relative growth of tradable and nontradable goods. ${ }^{18}$ In our example, those countries with low correlations increase their consumption of tradables by more, leading to an appreciation of the real exchange rate. The increase in stock market returns is followed by

\footnotetext{
${ }^{18}$ Remember that under these parameter assumptions, $p=C / S$, although the point about the relative growth of goods is general.
} 
a consumption boom that is not matched by an equally strong boom in services; this situation leads to higher prices. The low correlation allows these countries to take more aggressive positions in risky assets, increasing consumption relatively more than services. On the contrary, in countries with higher correlations, the increase of services is larger and the price level falls.

\subsection{Returns on entrepreneurial assets}

Nontradable assets are hardly new to the literature. Most of the time they are considered as an exogenous source of income that modifies the risk-taking behavior of investors. For example, portfolio choice theory examines the impact of nontradable assets on the demand for tradable assets. ${ }^{19}$ The international home bias literature argues that nontradable assets can explain (or, according to others, make it harder to understand) why investors prefer domestic stocks instead of a well-diversified portfolio with international stocks. $^{20}$ In this paper we endogenize the investment in the nontradable asset, instead of considering this asset as an endowment. ${ }^{21}$

The return on the entrepreneurial asset is endogenously determined in the model and is inversely related to the price level (see equation (13)). This return responds to standard asset pricing considerations. Higher $\sigma_{y}$ and higher $\rho$, which in a CAPM world increase the beta of the asset and therefore the expected return, also increase the return here (see $\mu_{k}$ in Table 5). The advantage of the approach in this paper is that the real exchange rate is an observable variable, making it easier to infer the return without

\footnotetext{
${ }^{19}$ Merton (1971) is the first analysis of the effects of nontradable income on portfolio choice. More recent applications include incomplete markets settings (Koo (1998), Svensson and Werner (1993)), and life-cycle portfolio problems (Campbell and Viceira (2002), Viceira (2000)).

${ }^{20}$ See Baxter and Jermann (1997) for the view that nontradable assets make the home bias puzzle even worse. Bottazzi, Pesenti, and van Wincoop (1996) present the opposing view. These two papers study human capital as the nontradable asset.

${ }^{21}$ A notable exception to the standard of considering nontradable assets as an exogenous source of income is the paper by Bodie, Merton, and Samuelson (1992). They underscore the fact that nontradable assets provide alternative margins of adjustment, for instance, the flexibility to work more or fewer hours in the case of human capital. In the same vein, Saks and Shore (2002) endogenize the choice of career, which is another important aspect of human capital. None of these papers endogenizes capital investments in nontradable assets as we do.
} 
estimating $\sigma_{y}$ or $\rho$.

Table 7 shows a simple exercise to illustrate this point. From the PWT we take the price levels for different countries, and we compute the implied return on the entrepreneurial asset from the model. The price indexes have the United States as a reference point; therefore we need first to determine the level of returns that serves as anchor. Moskowitz and Vissing-Jørgensen (2002) go through a careful analysis to compute the return on U.S. private equity. We set the U. S. return on entrepreneurial assets equal to the return they report for 1995, which is approximately 15 percent.

Table 7 shows impressive returns for China, equal to almost 150 times the initial investment. The entrepreneurial return decreases as the price level goes up. Is is interesting to see that, even among rich countries, there is a wide variation in the returns implied by the model. For instance, Canada has a return that is more than 10 percentage points higher than that of the U.S., while Japan and Switzerland have returns below 1 percent. This computation requires only the price level and other uncontroversial parameters. In particular, no information about risk aversion or risk characteristics is necessary, since it is all embedded in the price level. In a sense, we are doing asset pricing without data on covariances (with the market or consumption) in a departure from the standard practice. This may be an important departure, since these covariances are not observable in the case of entrepreneurial assets.

\subsection{Caveats and extensions}

This section comments briefly on some features of the model that can be solved differently. It also mentions possible extensions and interpretation issues.

\subsubsection{Labor and the stock market}

The model assumes that stock market assets use no labor. This assumption can be relaxed without affecting the results if the labor intensities of the technologies are preserved. In particular, we can assume that the stock market production function is a Cobb-Douglas function with labor intensity $\lambda<\nu$. Since returns on capital are still set in an international market, this assumption means that the capital-labor ratio is predetermined and the demand for labor from the stock market is some constant $\varphi$ times the capital 
investment $x W$. The total labor demand (normalized by wealth) is therefore $l+s+\varphi x$. The model presented in the paper is for the case where $\lambda=\varphi=0$.

\subsubsection{A minimalist interpretation of the model}

The model talks about stock market assets and entrepreneurial assets, but this labelling of sectors is not absolutely necessary. Some readers may prefer a more stylized interpretation. In particular, they may prefer a model in which there are just two sectors, $M$ and $Y$, and $M$ is more capital-intensive. Claims to the capital in both sectors are tradable, and therefore the domestic investor faces a given return on capital in both activities. ${ }^{22}$ The reduction of financial frictions introduces a comparative advantage $(\tau)$ in the capitalintensive sector, and consequently, the country specializes in this sector. The same implications for prices follow from this model.

Some disadvantages of this reading of the model are: (1) Stock market development is present in the model through $\tau$, but we cannot identify the growth of any particular sector with growth of the stock market; in fact, if both sectors are traded in financial markets, then it is not clear that the growth of one at expense of the other increases stock market capitalization; (2) Pricing entrepreneurial assets (that is, those assets excluded from financial markets) is in itself an interesting feature of the old model.

\subsubsection{International capital flight}

The substitution effect looks similar to a capital flight that results in a lower capital-labor ratio in the country and therefore lower wages. In this case, $M$ would represent the portfolio of all international assets. The problem with this interpretation is that it is hard to reconcile with the empirical findings. The stock market in the regressions would be a proxy for the fraction of wealth that is allocated to foreign assets. But this is already controlled for by using the accumulated current account balance, and that is not significant in the regressions. The explanatory power comes from the domestic stock market, not from holdings of foreign assets, signalling that the relevant reallocations do not necessarily involve cross-country capital flows. An international capital flight would reinforce the effects in this model, so we

\footnotetext{
${ }^{22}$ The case in which the entrepreneurial asset is tradable works like the previous case about stock market assets using labor. The capital-labor ratio is given, and labor demand is a residual.
} 
do not want to rule it out, but we stress that it is of second-order importance. In the data, the correlation between prices and accumulated current account surpluses is positive (see Table 3), and this also goes against the capital flight story.

\subsubsection{Caveats on the empirical measure of stock market wealth}

Following up on the previous point, the stock market capitalization of the empirical section of the paper may have problems when interpreted as $x$, the fraction of wealth in the stock market. A first, obvious point is that the empirical measure is a fraction of GDP, not of wealth. This limitation is imposed by the data, since estimates of country wealth are unreliable.

A second, more important point, is that the empirical measure is an indirect measure of domestic wealth allocated to the stock market. The stock market capitalization measure does not provide information about domestic holdings of foreign assets or domestic assets in foreign hands. In other words, a higher stock market capitalization could be the result of reduced holdings of foreign assets in the hands of local investors, or increased holdings of local assets in the hands of foreigners. In neither case this would imply a smaller entrepreneurial sector, as is essential to the mechanism in the paper.

We argue that the empirical measure is still a good proxy for three reasons. First, the net foreign asset position is already controlled for in the regressions. Second, the home bias literature (French and Poterba (1991), Lewis (1999)) shows that investors hold mostly domestic assets, and therefore that domestic capitalization is a good proxy for investors' total holdings of financial assets. There is some evidence that the home bias is negatively correlated with stock market size, meaning that countries with large stock markets invest a larger fraction of their portfolios in foreign equity (Shore and White (2003)). If anything, domestic and foreign investments seem to be positively correlated, reinforcing and not cancelling each other out. Finally, it is hard to argue that foreign investors absorb all of the increase in stock market capitalization and that domestic investors are kept outside. For example, it is often the case that companies that go public offer stocks to employees. The same can be said about privatizations in developing countries. 


\subsubsection{Issues relevant for home-bias in stocks}

This model does not distinguish between domestic and foreign stocks; therefore, it ignores home-bias issues. The model has some features that have been explored differently in the home-bias literature. First, in this model workers do not consume the nontradable good. In DeMarzo, Kaniel, and Kremer (2004), those agents that are constrained to hold the local resource also consume the local good. This induces a home bias in the unconstrained investors who have to compete for the local good. Tesar (1993) also studies the role of nontradable goods in the home bias.

Second, we separate the owners of capital from the owners of labor. This implies that the model abstracts from the hedging demands mentioned by Baxter and Jermann (1997). They argue that local stocks are a bad hedge against the returns on nontradable human capital, making the observed home bias even more puzzling. Our assumption is more in line with Bottazzi, Pesenti, and van Wincoop (1996), who view workers and capitalists as separate groups.

\subsubsection{Other nontradable factors}

We identify the nontradable resource with labor. Other local resources can include political favors that the entrepreneur gets from the local authorities or trust among members of a community. Intangible resources like these may be very important for entrepreneurship.

\subsubsection{Entrepreneurs and their own labor effort}

Perhaps the most natural interpretation of an entrepreneur is an agent that applies his own effort to increase the return on investment. Unfortunately, the model where the entrepreneur is endowed with labor is not tractable. The main complication consists in computing a comprehensive measure of wealth when making portfolio decisions. Comprehensive wealth includes the future endowments of time that the entrepreneur can assign to labor. Two issues arise: what price to use between consumption and leisure at each point in time, and how to discount the future endowments of time. ${ }^{23}$ In order to

\footnotetext{
${ }^{23}$ It is probably more intuitive to think of an agent endowed with two different goods, for example, apples and oranges. When computing the agent's wealth, the first issue is the relative price of apples and oranges, that is, the intra-period rate of substitution. The second issue is that the endowment of, say, oranges is spread in time, and the future
} 
do this, the entrepreneur needs to know the stochastic process for the wage, which is endogenously determined in the model. When the wage is constant and therefore safe, this task is easy, but a constant price relies on a particular assumption about the endowment of time that may not be applicable to entrepreneurs. Bodie, Merton, and Samuelson (1992) analyze the case of a risky wage in a complete market and study in more detail the impact of human wealth on portfolio selection. We conjecture that introducing leisure does not invalidate the basic results. Furthermore, separating the supply and demand of labor makes the model more suitable for cases where the entrepreneur is not endowed with the nontradable resource. Also, the entrepreneur's own effort could be a small, perhaps insignificant, margin of adjustment when compared with other inputs required in the production function.

\section{Conclusions}

This paper offers three main contributions. First, it documents a new fact: stock market development has a non-monotonic effect on relative prices, increasing prices in the beginning, then decreasing prices. In other words, financial development has a non-monotonic effect on the real exchange rate. Second, this paper provides an explanation for the non-monotonic effect, based on the nature of the technologies that underlie stock market assets, namely, that these assets are more capital-intensive. Equivalently, stock market development represents a comparative advantage to capital-intensive sectors. Finally, the model provides a framework for pricing entrepreneurial assets.

The relevance of this result is most obvious for international economics, since the real exchange rate is an important price in matters such as the current account balance. The change in relative prices also has implications for goods and labor markets. As noted by Blanchard (2004), financial deregulation (an exogenous decrease in $\tau$ ) can lead to substantial changes in real wages. This paper shows how this can happen, and it also gives an idea of what parameters are relevant to determining the impact of financial deregulation on wages. More generally, the model illustrates a channel

oranges need to be discounted when computing today's wealth (by the intertemporal rate of substitution or the appropriate discount rate). In terms of apples, there is no need to discount the endowment if it is all given today. 
through which the effects of financial development spread to the rest of the real economy.

From the policy standpoint, it is important that stock market development raises wages in the beginning. It is a "win-win situation," where capitalists and workers increase their welfare (at least in this model). The decrease in wages that occurs at some point as the stock market keeps developing may explain why some countries fail to develop their financial systems to the maximum or why they fail to eliminate all regulations. How these political considerations determine the actual level of financial development in a country is an interesting area of present and future research (see Rajan and Zingales (2003)). 


\section{Appendix}

After substituting the guess for the value function into the Bellman equation, we obtain

$$
\begin{gathered}
\Psi\left(p^{*}\right)= \\
\frac{1}{\Omega}\left\{r-\frac{\delta}{1-\gamma}+\frac{1}{2 \gamma\left(1-\rho^{2}\right) \sigma_{y}^{2}}\left[\left(\mu_{k}^{*}-r\right)^{2}-2 \beta\left(\mu_{k}^{*}-r\right)\left(\mu_{m}-r\right)\right.\right. \\
\left.\left.+\left(\frac{\sigma_{y}}{\sigma_{m}}\right)^{2}\left(\mu_{m}-r\right)^{2}\right]\right\},
\end{gathered}
$$

where

$$
\Omega=\left[\frac{\gamma \eta^{\frac{1-\gamma}{\gamma}}}{\gamma-1}\right]\left[\frac{1-\eta}{\eta p^{*}}\right]^{\frac{(1-\gamma)(1-\eta)}{\gamma}} .
$$




\section{References}

[1] Baxter, M., and U. Jermann (1997), The International Diversification Puzzle Is Worse Than You Think, American Economic Review 87, 170180.

[2] Beck, T., A. Demirgüç-Kunt, and R. Levine (1999), A New Database on Financial Development and Structure, World Bank.

[3] Bergstrand, J. H. (1991), Structural Determinants of Real Exchange Rates and National Price Levels: Some Empirical Evidence, American Economic Review 81, 325-334.

[4] Bhagwati, J. N. (1984), Why Are Services Cheaper In The Poor Countries?, The Economic Journal 94, 279-286.

[5] Blanchard, O. (2004), The Economic Future of Europe, Journal of Economic Perspectives 18, 3-26.

[6] Blanchard, O. and F. Giavazzi (2003), Macroeconomic Effects of Regulation and Deregulation in Goods and Labor Markets, Quarterly Journal of Economics 118, 879-909.

[7] Bodie, Z., R.C. Merton and W. Samuelson (1992), Labor Supply Flexibility and Portfolio Choice in a Life Cycle Model, Journal of Economic Dynamics and Control 16, 427-449.

[8] Botero J.C., S. Djankov, R. La Porta, F. Lopez-de-Silanes, and A. Shleifer (2004), The Regulation of Labor, Quarterly Journal of Economics 119, 1139-1382.

[9] Bottazzi, L., P. Pesenti and E. van Wincoop (1996), Wages, Profits and the International Portfolio Puzzle, European Economic Review 40, 219-254.

[10] Brandt, M., J. Cochrane, and P. Santa-Clara (2005), International Risk Sharing is Better Than You Think or Exchange Rates are Too Smooth, forthcoming Journal of Monetary Economics.

[11] Campbell, J.Y. and L. Viceira (2002), Strategic Asset Allocation: Portfolio Choice for Long-Term Investors, Oxford University Press. 
[12] Carlin, W., and C. Mayer (2003), Finance, Investment, and Growth, Journal of Financial Economics 69, 191-226.

[13] Cox, J.C., J.E. Ingersoll and S. Ross (1985), An Intertemporal General Equilibrium Model of Asset Prices, Econometrica 53, 363-384.

[14] DeMarzo, P., R. Kaniel and I. Kremer (2004), Diversification as a Public Good: Community Effects in Portfolio Choice, The Journal of Finance 59, 1677-1715.

[15] Djankov, S., R. La Porta, F. Lopez-de-Silanes, and A. Shleifer (2002), The Regulation of Entry, Quarterly Journal of Economics 117, 1-37.

[16] French, K. and J. Poterba (1991), International Diversification and International Equity Markets, American Economic Review 81, 222-226.

[17] Froot, K. and K. Rogoff (1995), Perspectives on PPP and Long-Run Real Exchange Rates, in Handbook of International Economics vol. 3, Gene Grossman and Kenneth Rogoff (eds.), 1647-88.

[18] King, R. and S. Rebelo (1999), Resuscitating Real Business Cycles, Handbook of Macroeconomics, edited by M. Woodford and J. Taylor.

[19] Koo, H.K. (1998), Consumption and Portfolio Selection with Labor Income: A Continuous Time Approach, Mathematical Finance 8, 49-65.

[20] Kraay, A., N. Loayza, L. Serven, and J. Ventura (2000), Country Portfolios, NBER Working Paper 7795.

[21] Lane, P. and G. Milesi-Ferretti (2001), The External Wealth of Nations: Measures of Foreign Assets and Liabilities for Industrial and Developing Countries, Journal of International Economics 55, 263-294.

[22] Lane, P. and G. Milesi-Ferretti (2004), The Transfer Problem Revisited: Net Foreign Assets and Real Exchange Rates, Review of Economics and Statistics 86, 841-857.

[23] La Porta, R., F. Lopez-de-Silanes, A. Shleifer, and R. Vishny (1997), Legal Determinants of External Finance, The Journal of Finance 52, 1131-1150. 
[24] La Porta, R., F. Lopez-de-Silanes, A. Shleifer, and R. Vishny (1998), Law and Finance, Journal of Political Economy 106, 1113-55.

[25] La Porta, R., F. Lopez-de-Silanes, A. Shleifer, and R. Vishny (1999), The Quality of Government, Journal of Law, Economics and Organization 15, 222-279.

[26] Levine, R. (2004), Finance and Growth: Theory and Evidence, NBER Working Paper 10776. Forthcoming in the Handbook of Economic Growth.

[27] Lewis, K. (1999), Trying to Explain Home Bias in Equities and Consumption, Journal of Economic Literature 37, 571-608.

[28] Merton, R.C. (1969), Lifetime Portfolio Selection Under Uncertainty: the Continuous-time Case, Review of Economics and Statistics 51, 247257.

[29] Merton, R.C. (1971), Optimum Consumption and Portfolio Rules in a Continuous Time Model, The Journal of Economic Theory 3, 373-413.

[30] Morck, R., B. Yeung, and W. Yu (2000), The Information Content of Stock Markets: Why Do Emerging Markets Have Synchronous Stock Price Movements?, Journal of Financial Economics 58, 215-260.

[31] Moskowitz, T. and A. Vissing-Jørgensen (2002), The Returns to Entrepreneurial Investment: A Private Equity Puzzle? American Economic Review 92, 745-778.

[32] Obstfeld, M. (1994), Risk-Taking, Global Diversification, and Growth, American Economic Review 84, 1310-1329.

[33] Obstfeld, M. and K. Rogoff (1996), Foundations of International Macroeconomics, MIT Press.

[34] Obstfeld, M. and K. Rogoff (2000), New Directions for Stochastic Open Economy Models, Journal of International Economics 50, 117-153.

[35] Obstfeld, M. and K. Rogoff (2004), The Unsustainable U.S. Current Account Position Revisited, NBER Working Paper 10869. 
[36] Rajan, G. R. and L. Zingales (1998), Financial Dependence and Growth, American Economic Review 88, 559-586.

[37] Rajan, G. R. and L. Zingales (2003), The Great Reversals: The Politics of Financial Development in the Twentieth Century, Journal of Financial Economics 69, 5-50.

[38] Richard, S.F. and S.M. Sundaresan (1981), A Continuous Time Equilibrium Model of Forward Prices and Futures Prices in a Multigood Economy, Journal of Financial Economics 9, 347-371.

[39] Rogoff, K.(1996), The Purchasing Power Parity Puzzle, Journal of Economic Literature 34, 647-668.

[40] Saks, R. and S.H. Shore (2002), Risk and Career Choice, Working Paper, Harvard University.

[41] Shore, S.H. and J. White (2003), External Habit Formation and the Home Bias Puzzle, Working Paper Wharton School of Business.

[42] Stein, J. C. (2003), Agency, Information and Corporate Investment, Handbook of the Economics of Finance, edited by G. M. Constantinides, M. Harris and R. Stulz.

[43] Summers, R. and A. Heston (1991), The Penn World Table (Mark 5): An Expanded Set of International Comparisons, 1950-1988, Quarterly Journal of Economics 106, 327-368.

[44] Sundaresan, S.M. (1984), Consumption and Equilibrium Interest Rates in Stochastic Production Economies, The Journal of Finance 39, 77-92.

[45] Svaleryd, H., and J. Vlachos (2005), Financial Markets, Industrial Specialization and Comparative Advantage, European Economic Review 49, 113-144.

[46] Svensson, L. and I. Werner (1993), Nontraded Assets in Incomplete Markets: Pricing and Portfolio Choice, European Economic Review 37, 1149-1168

[47] Taylor, A.M. and M.P. Taylor (2004), The Purchasing Power Parity Debate, Journal of Economic Perspectives 18, 135-158. 
[48] Tesar, L. (1993), International Risk-sharing and Non-traded Goods, Journal of International Economics 35, 69-89.

[49] Viceira, L. (2001), Optimal Portfolio Choice for Long-Horizon Investors with Nontradable Labor Income, The Journal of Finance 56, 433-470. 


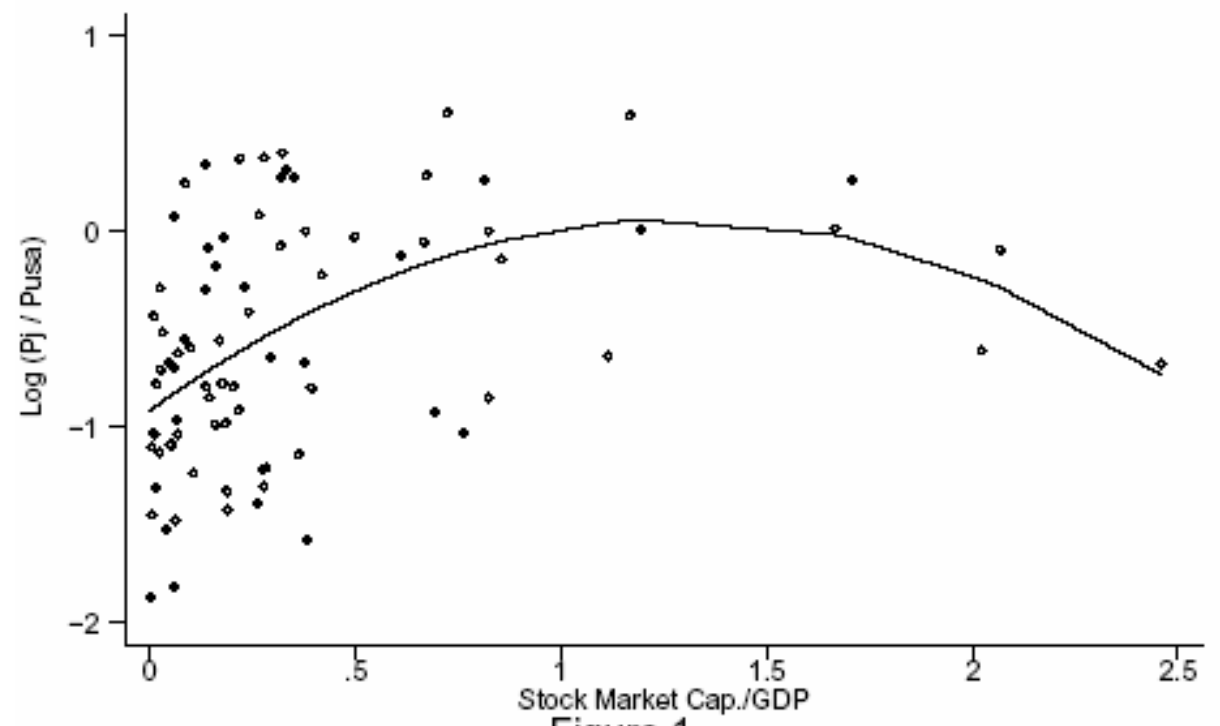

Figure 1 

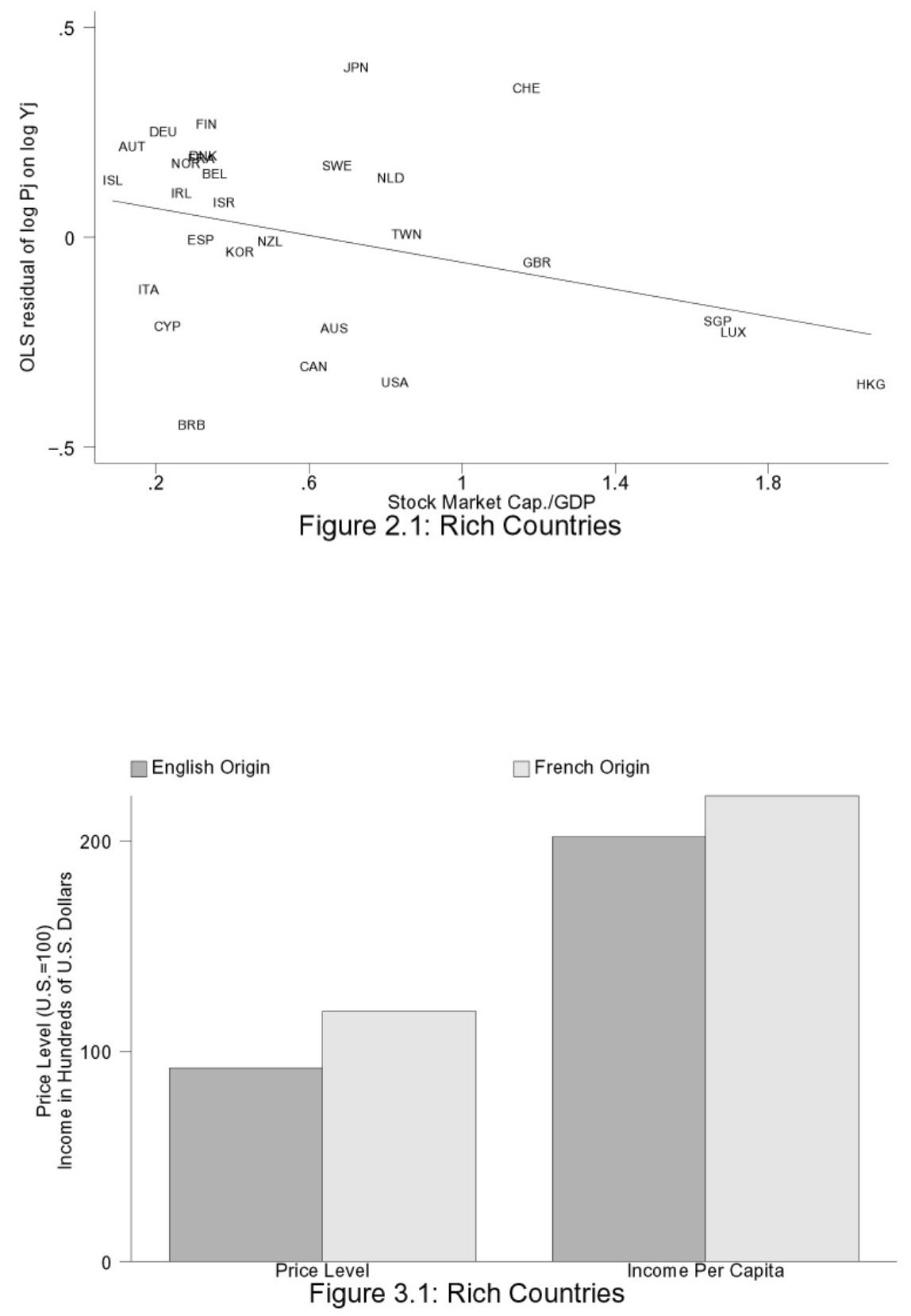
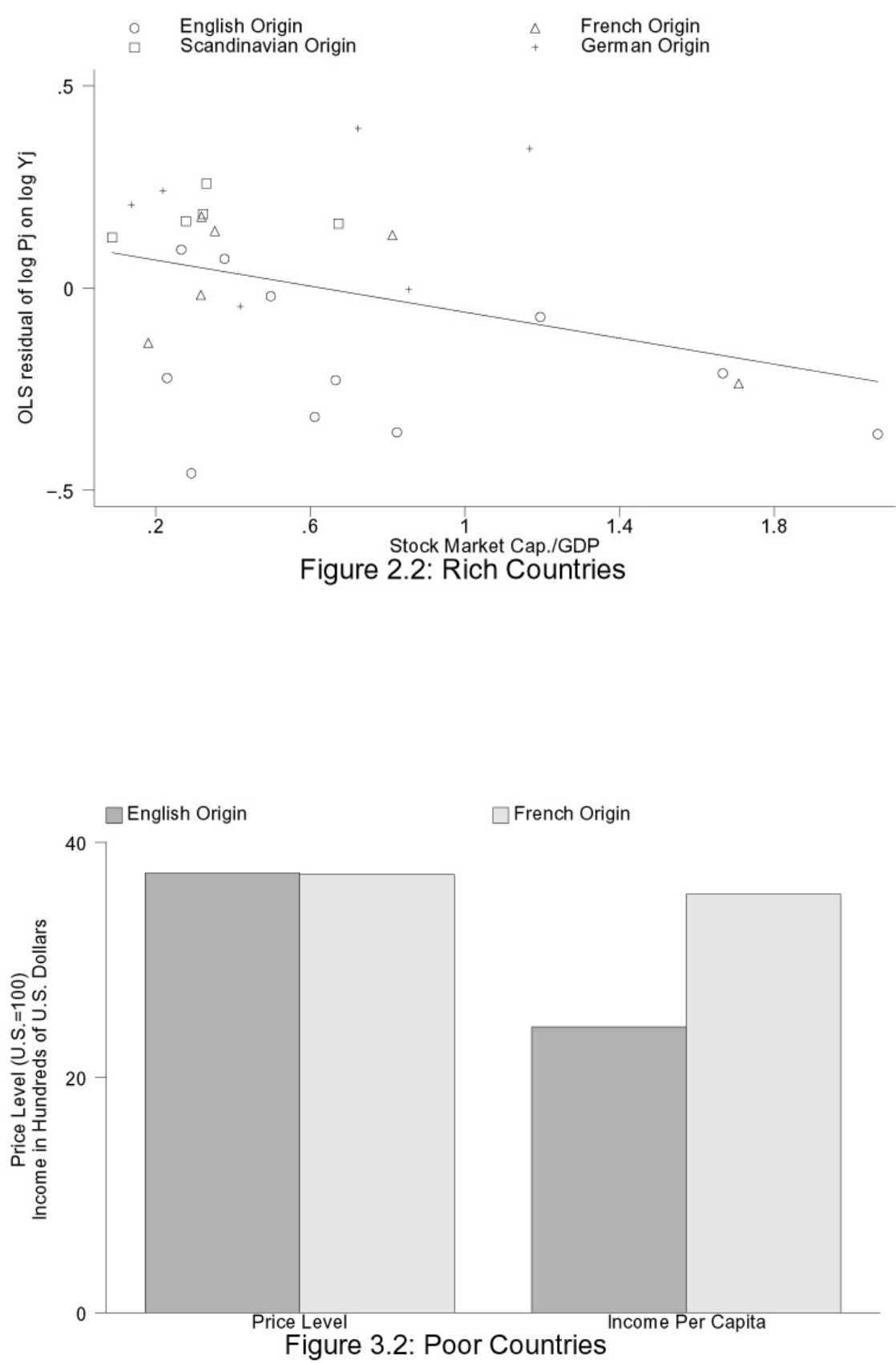


\section{Table 1}

\section{The Effect of Stock Market Capitalization on Prices: Basic Result}

The dependent variable is the price level relative to the U.S. in the year 1995, taken from the Penn World Table 6.1. The independent variables are: (1) Stock market capitalization over GDP in 1995, from Beck et al. (1999), and its quadratic term, and (2) Log of per capita income relative to the U.S. in 1995, from the Penn World Table 6.1. In the IV regressions the instruments for the stock market capitalization are a set of dummies reflecting the legal origin of the country (English, French, German, Scandinavian or Socialist). The constant in the regression is not reported. Robust standard errors are reported below the coefficients. Significance: $* 10 \%, * * 5 \%, * * * 1 \%$.

\begin{tabular}{|c|c|c|c|c|c|c|c|c|c|c|c|c|c|c|c|c|c|c|}
\hline & OLS & & IV & & OLS & & IV & & OLS & & OLS & & IV & & OLS & & IV & \\
\hline & 1 & & 2 & & 3 & & 4 & & 5 & & 6 & & 7 & & 8 & & 9 & \\
\hline \multirow[t]{2}{*}{ Stock Market Cap. } & 0.402 & $* * *$ & 0.796 & $* *$ & 1.516 & $* * *$ & 4.988 & $* * *$ & & & 0.026 & & 0.311 & & 0.422 & $* *$ & 3.264 & $* * *$ \\
\hline & 0.137 & & 0.341 & & 0.317 & & 1.164 & & & & 0.058 & & 0.219 & & 0.199 & & 0.848 & \\
\hline \multirow[t]{2}{*}{$(\text { Stock Market Cap.) })^{2}$} & & & & & -0.586 & $* * *$ & -2.866 & $* * *$ & & & & & & & -0.199 & $* *$ & -1.792 & $* * *$ \\
\hline & & & & & 0.139 & & 1.010 & & & & & & & & 0.081 & & 0.576 & \\
\hline \multirow[t]{2}{*}{ Log Income } & & & & & & & & & 0.551 & $* * *$ & 0.546 & $* * *$ & 0.485 & $* * *$ & 0.519 & $* * *$ & 0.381 & $* * *$ \\
\hline & & & & & & & & & 0.075 & & 0.080 & & 0.101 & & 0.082 & & 0.123 & \\
\hline $\mathrm{R}^{2}$ & 0.108 & & & & 0.219 & & & & 0.652 & & 0.652 & & & & 0.664 & & & \\
\hline $\mathrm{N}$ & 82 & & 82 & & 82 & & 82 & & 82 & & 82 & & 82 & & 82 & & 82 & \\
\hline First-stage F-statistic & & & 12.8 & & & & 12.8 & & & & & & 8.93 & & & & 8.93 & \\
\hline J-test & & & 14.694 & & & & 3.398 & & & & & & 18.790 & & & & 1.497 & \\
\hline p-value J-test & & & 0.002 & & & & 0.183 & & & & & & 0.000 & & & & 0.473 & \\
\hline
\end{tabular}


Table 2

The Effect of Stock Market Capitalization on Prices by Country Sub-samples

The dependent variable is the price level relative to the U.S. in the year 1995, taken from the Penn World Table 6.1. The independent variables are: (1) Stock market capitalization over GDP in 1995, from Beck et al. (1999), and (2) Log of per capita income relative to the U.S. in 1995, from the Penn World Table 6.1. In the IV regressions the instruments for the stock market capitalization are a set of dummies reflecting the legal origin of the country (English, French, German, Scandinavian or Socialist). In the top panel the sample is split in three according to the size of the stock market (small-medium-big), and in the lower panel according to per capita income (poor-middle-rich). The constant in the regression is not reported. Robust standard errors are reported below the coefficients. Significance: $* 10 \%, * * 5 \%, * * * 1 \%$.

\begin{tabular}{|c|c|c|c|c|c|c|c|c|c|c|c|c|}
\hline \multirow[b]{4}{*}{ Stock Market Cap. } & \multirow{2}{*}{\multicolumn{3}{|c|}{$\begin{array}{c}\text { Small Stock Mkt. } \\
(\mathrm{N}=27)\end{array}$}} & & \multirow{2}{*}{\multicolumn{3}{|c|}{$\frac{\text { Medium Stock Mkt. }}{(\mathrm{N}=27)}$}} & & \multicolumn{3}{|c|}{ Big Stock Mkt. } & \\
\hline & & & & & & & & \multicolumn{4}{|c|}{$(\mathrm{N}=28)$} & \\
\hline & OLS & & IV & & OLS & & IV & & OLS & & IV & \\
\hline & 4.961 & * & 14.818 & *** & 0.138 & & -2.448 & & -0.094 & & -0.497 & ** \\
\hline & 2.652 & & 4.611 & & 0.810 & & 2.298 & & 0.069 & & 0.195 & \\
\hline \multirow[t]{5}{*}{ Log Income } & 0.298 & & 0.316 & $*$ & 0.582 & $* * *$ & 0.587 & $* * *$ & 0.673 & $* * *$ & 0.719 & $* * *$ \\
\hline & 0.214 & & 0.190 & & 0.062 & & 0.077 & & 0.055 & & 0.071 & \\
\hline & \multicolumn{3}{|c|}{ Poor Countries } & & \multicolumn{3}{|c|}{ Middle Income } & & \multicolumn{3}{|c|}{ Rich Countries } & \\
\hline & \multicolumn{3}{|c|}{$(\mathrm{N}=27)$} & & \multicolumn{3}{|c|}{$(\mathrm{N}=27)$} & & \multicolumn{3}{|c|}{$(\mathrm{N}=28)$} & \\
\hline & OLS & & IV & & OLS & & IV & & OLS & & IV & \\
\hline \multirow[t]{2}{*}{ Stock Market Cap. } & 0.062 & & 2.518 & $* *$ & 0.029 & & 0.162 & & -0.220 & $* * *$ & -0.625 & $* * *$ \\
\hline & 0.275 & & 1.217 & & 0.050 & & 0.132 & & 0.060 & & 0.235 & \\
\hline \multirow[t]{2}{*}{ Log Income } & 0.129 & & 0.101 & & 0.445 & $*$ & 0.443 & $*$ & 1.014 & $* * *$ & 1.521 & $* * *$ \\
\hline & 0.282 & & 0.333 & & 0.251 & & 0.243 & & 0.255 & & 0.314 & \\
\hline
\end{tabular}


Table 3

The Effect of Stock Market Capitalization on Prices: Additional Controls

The dependent variable is the price level relative to the U.S. in the year 1995, taken from the Penn World Table 6.1. The independent variables are: (1) Stock market capitalization over GDP in 1995, from Beck et al. (1999), and its quadratic term, (2) Log of per capita income relative to the U.S. in 1995, from the Penn World Table 6.1., (3) Log of government expenditures over GDP in 1995, (4) Accumulated current account balance as percentage of GDP from 1990 to 1995, (5) Terms of trade (TOT) average growth from 1990 to 1995, (6) GDP (rgdpch from the Penn World Table) average growth from 1990 to 1995. The instruments for the stock market capitalization are a set of dummies reflecting the legal origin of the country (English, French, German, Scandinavian or Socialist). The constant in the regression is not reported. Robust standard errors are reported below the coefficients. Significance: $* 10 \%,{ }^{* *} 5 \%,{ }^{* * *} 1 \%$.

\begin{tabular}{|c|c|c|c|c|c|c|c|c|c|c|}
\hline & IV & & IV & & IV & & IV & & IV & \\
\hline & 1 & & 2 & & 3 & & 4 & & 5 & \\
\hline \multirow[t]{2}{*}{ Stock Market Cap. } & 3.089 & $* * *$ & 3.779 & $* * *$ & 3.197 & $* * *$ & 3.752 & $* * *$ & 3.339 & $* * *$ \\
\hline & 0.998 & & 0.978 & & 0.917 & & 1.021 & & 1.153 & \\
\hline \multirow[t]{2}{*}{$\left(\right.$ Stock Market Cap.) ${ }^{2}$} & -1.849 & $* *$ & -2.241 & $* * *$ & -1.716 & $* * *$ & -2.000 & $* * *$ & -1.947 & $* *$ \\
\hline & 0.756 & & 0.760 & & 0.577 & & 0.651 & & 0.824 & \\
\hline \multirow[t]{2}{*}{ Log Income } & 0.489 & $* * *$ & 0.336 & $* * *$ & 0.373 & $* * *$ & 0.346 & $* *$ & 0.405 & $* * *$ \\
\hline & 0.117 & & 0.126 & & 0.130 & & 0.137 & & 0.127 & \\
\hline \multirow[t]{2}{*}{ Government Exp. } & 0.273 & & & & & & & & 0.856 & \\
\hline & 0.619 & & & & & & & & 0.694 & \\
\hline \multirow[t]{2}{*}{ Acummulated Current Acc. } & & & 0.643 & & & & & & 0.490 & \\
\hline & & & 0.818 & & & & & & 0.764 & \\
\hline \multirow[t]{2}{*}{ TOT Average Growth } & & & & & -0.438 & & & & 0.223 & \\
\hline & & & & & 1.064 & & & & 0.911 & \\
\hline \multirow[t]{2}{*}{ GDP Average Growth } & & & & & & & -1.929 & & 1.277 & \\
\hline & & & & & & & 3.808 & & 4.496 & \\
\hline $\mathrm{N}$ & 70 & & 80 & & 78 & & 81 & & 66 & \\
\hline First-stage F-statistic & 6.83 & & 8.7 & & 7.17 & & 3.8 & & 3.6 & \\
\hline J-test & 0.977 & & 0.920 & & 1.690 & & 1.157 & & 0.583 & \\
\hline p-value J-test & 0.614 & & 0.631 & & 0.430 & & 0.561 & & 0.747 & \\
\hline
\end{tabular}




\section{Table 4}

\section{Are Legal Origins Working Through the Stock Market?}

The dependent variable is the price level relative to the U.S. in the year 1995, taken from the Penn World Table 6.1. The independent variables are: (1) Stock market capitalization over GDP in 1995, from Beck et al. (1999), and its quadratic term, (2) Log of the number of procedures from Djankov et al. (2002), (3) Labor law index from Botero et al. (2004), and (4) Log of per capita income relative to the U.S. in 1995, from the Penn World Table 6.1. In the IV regressions, the stock market, the number of procedures and the labor law index are considered as endogenous. The instruments are a set of dummies reflecting the legal origin of the country (English, French, German, Scandinavian or Socialist). The constant in the regression is not reported. Robust standard errors are reported below the coefficients. Significance: $* 10 \%, * * 5 \%, * * * 1 \%$.

\begin{tabular}{|c|c|c|c|c|c|c|c|c|}
\hline & OLS & & IV & & OLS & & IV & \\
\hline & 1 & & 2 & & 3 & & 4 & \\
\hline \multirow[t]{2}{*}{ Stock Market Cap. } & 0.429 & $*$ & 3.041 & $* * *$ & 0.321 & & 3.169 & $* *$ \\
\hline & 0.228 & & 0.770 & & 0.219 & & 1.406 & \\
\hline \multirow[t]{2}{*}{$(\text { Stock Market Cap. })^{2}$} & -0.211 & $* *$ & -1.719 & $* * *$ & -0.194 & $* *$ & -1.604 & $* * *$ \\
\hline & 0.093 & & 0.509 & & 0.083 & & 0.595 & \\
\hline \multirow[t]{2}{*}{ Log Number of Procedures } & -0.067 & & -0.176 & & & & & \\
\hline & 0.109 & & 0.191 & & & & & \\
\hline \multirow[t]{2}{*}{ Labor Law Index } & & & & & -0.652 & & 0.429 & \\
\hline & & & & & 0.484 & & 5.489 & \\
\hline \multirow[t]{2}{*}{ Log Income } & 0.516 & $* * *$ & 0.381 & $* *$ & 0.590 & $* * *$ & 0.343 & \\
\hline & 0.116 & & 0.154 & & 0.079 & & 0.678 & \\
\hline $\mathrm{R}^{2}$ & 0.654 & & & & 0.662 & & & \\
\hline $\mathrm{N}$ & 67 & & 67 & & 67 & & 67 & \\
\hline First-stage F-statistic & & & 10.25 & & & & 10.25 & \\
\hline J-test & & & 0.032 & & & & 0.559 & \\
\hline p-value J-test & & & 0.859 & & & & 0.455 & \\
\hline
\end{tabular}


Table 5

Comparative Statics

The equilibrium price of services and the return on the entrepreneurial asset are in percentage terms. Holdings of the entrepreneurial asset and the stock market are in percentages of wealth. Consumption is in dollar amounts. Services correspond to the percentage of total labor that works in services. The last column reports the capital/labor ratio in the entrepreneurial asset. Baseline parameters are $\delta=0.04, \gamma=5, \eta=0.5, r=0.02, \rho=0.3, \sigma_{\mathrm{y}}=\sigma_{\mathrm{m}}=0.12, \mu_{\mathrm{y}}=\mu_{\mathrm{m}}=0.06, \nu=0.7, \theta=1$, $\mathrm{W}=\$ 100,000$.

\begin{tabular}{cccccccccc}
\hline & & $\mathrm{p}^{*}$ & $\mu_{\mathrm{k}}$ & $\mathrm{k}$ & $\mathrm{x}$ & $\mathrm{k} / \mathrm{x}$ & $\mathrm{C}$ & $\mathrm{S}$ & $\mathrm{K} / \mathrm{L}$ \\
\hline$\gamma$ & 2 & 3.16 & 3.5 & 11.4 & 135.5 & 0.08 & 2,197 & 70 & 0.38 \\
& 5 & 2.96 & 4.07 & 13.3 & 51.6 & 0.26 & 1,668 & 56 & 0.30 \\
& 10 & 2.76 & 4.79 & 12.1 & 24.1 & 0.50 & 1,394 & 50 & 0.25 \\
& 20 & 2.55 & 5.77 & 9.8 & 10.9 & 0.90 & 1,241 & 49 & 0.19 \\
& 50 & 2.28 & 7.49 & 6.5 & 3.6 & 1.82 & 1,143 & 50 & 0.13 \\
\hline$\theta$ & 0.5 & 3.28 & 3.2 & 0.0 & 55.6 & 0.00 & 1,644 & 100 & - \\
& 1 & 2.96 & 4.07 & 13.3 & 51.6 & 0.26 & 1,668 & 56 & 0.30 \\
& 2 & 2.68 & 5.13 & 29.5 & 46.7 & 0.63 & 1,759 & 33 & 0.22 \\
& 5 & 2.34 & 7.05 & 58.8 & 37.9 & 1.55 & 2,095 & 18 & 0.14 \\
& 10 & 2.11 & 8.97 & 88.1 & 29.1 & 3.02 & 2,662 & 13 & 0.10 \\
\hline$\rho$ & -0.8 & 4.90 & 1.26 & 94.9 & 131.5 & 0.72 & 2,110 & 43 & 1.67 \\
& -0.5 & 3.87 & 2.18 & 40.4 & 75.7 & 0.53 & 1,819 & 47 & 0.76 \\
& 0 & 3.21 & 3.37 & 19.0 & 55.6 & 0.34 & 1,696 & 53 & 0.40 \\
& 0.5 & 2.81 & 4.60 & 11.1 & 50.0 & 0.22 & 1,658 & 59 & 0.27 \\
& 0.8 & 2.62 & 5.41 & 8.1 & 49.1 & 0.17 & 1,647 & 63 & 0.22 \\
\hline
\end{tabular}




\section{Table 6}

Interpretation of Empirical Results Using the Model

The table shows the effect of increasing the return on the stock market $\left(\mu_{\mathrm{m}}\right)$ under different values of the correlation between the stock market and the entrepreneurial asset $(\rho)$. The stock market expected return increases from $6 \%$ to $8 \%$ in both cases. The table reports the percentage growth in each variable. Baseline parameters are $\delta=0.04, \gamma=5, \eta=0.5, r=0.02, \sigma_{y}=\sigma_{m}=0.12, \mu_{y}=0.06, \nu=0.7, \theta=1, W=\$ 100,000$.

\begin{tabular}{lcccccc}
\hline & $\mathrm{p}^{*}$ & $\mathrm{k}$ & $\mathrm{x}$ & $\mathrm{C}$ & $\mathrm{S}$ & $\mathrm{K} / \mathrm{L}$ \\
\hline Case $\rho=0.3$ & $-2 \%$ & $-46 \%$ & $57 \%$ & $32 \%$ & $35 \%$ & $-2 \%$ \\
Case $\rho=0$ & $4 \%$ & $-20 \%$ & $50 \%$ & $32 \%$ & $27 \%$ & $36 \%$ \\
\hline
\end{tabular}


Table 7

\section{Price Levels and the Return on the Entrepreneurial Asset}

The table shows price levels in 1995 from the Penn World Table 6.1 and the imputed return on the nontradable asset $\left(\mu_{\mathrm{k}}\right)$. The return on the nontradable asset for the U.S. is set at $15 \%$ following Moskowitz and Vissing-Jorgensen (2002). Using equations (13) and (20) we get the price of nontradables and the price level in the U.S. consistent with a $15 \%$ return. We obtain a price level for each country multiplying the U.S. price level by the ratio of price levels with respect to the U.S. from the Penn World Table. The price of nontradables for each country then follows from equation (20). Feeding these prices into equation (13) delivers the imputed return on the entrepreneurial asset. The relevant parameters used for this exercise are $\eta=0.5$ and $\nu=0.7$.

\begin{tabular}{ccc}
\hline & $\begin{array}{c}\text { Price Level } \\
\text { (U.S.=100) }\end{array}$ & $\begin{array}{c}\mu_{\mathrm{k}} \\
\text { (U.S. }=15 \%)\end{array}$ \\
\hline China & 22.8 & $14804 \%$ \\
Russian Federation & 32.3 & $2937 \%$ \\
Mexico & 44.8 & $637 \%$ \\
Malaysia & 50.8 & $354 \%$ \\
Brazil & 66.3 & $102 \%$ \\
Argentina & 74.0 & $61 \%$ \\
Canada & 88.5 & $27 \%$ \\
Italy & 96.8 & $17 \%$ \\
United States & $\mathbf{1 0 0 . 0}$ & $\mathbf{1 5 \%}$ \\
France & 132.3 & $4.1 \%$ \\
Germany & 145.6 & $2.6 \%$ \\
Switzerland & 181.0 & $0.9 \%$ \\
Japan & 183.5 & $0.9 \%$ \\
\hline
\end{tabular}


Table A.1 Data Appendix (Year 1995)

\begin{tabular}{|c|c|c|c|c|}
\hline Country & Price Level (U.S. $=100)$ & Income (U.S. $=100)$ & Stock Market Cap. / GDP & Legal Origin \\
\hline Australia & 94.74 & 78.05 & 0.665 & English \\
\hline Bangladesh & 21.75 & 5.16 & 0.041 & English \\
\hline Barbados & 52.61 & 48.07 & 0.292 & English \\
\hline Botswana & 57.82 & 20.80 & 0.085 & English \\
\hline Canada & 88.49 & 80.48 & 0.611 & English \\
\hline Cyprus & 75.58 & 57.07 & 0.229 & English \\
\hline Fiji & 49.31 & 18.44 & 0.025 & English \\
\hline Ghana & 29.55 & 4.59 & 0.274 & English \\
\hline Hong Kong, China & 91.11 & 88.68 & 2.068 & English \\
\hline India & 20.74 & 6.99 & 0.382 & English \\
\hline Ireland & 108.82 & 60.87 & 0.266 & English \\
\hline Israel & 100.21 & 56.11 & 0.378 & English \\
\hline Jamaica & 51.22 & 13.43 & 0.375 & English \\
\hline Kenya & 27.14 & 4.39 & 0.277 & English \\
\hline Malaysia & 50.81 & 30.05 & 2.459 & English \\
\hline Namibia & 49.86 & 15.54 & 0.059 & English \\
\hline Nepal & 16.27 & 4.38 & 0.058 & English \\
\hline New Zealand & 97.42 & 61.21 & 0.497 & English \\
\hline Nigeria & 107.46 & 2.71 & 0.059 & English \\
\hline Pakistan & 26.43 & 6.73 & 0.186 & English \\
\hline Singapore & 101.32 & 83.55 & 1.667 & English \\
\hline South Africa & 54.49 & 25.40 & 2.023 & English \\
\hline Sri Lanka & 24.08 & 10.72 & 0.188 & English \\
\hline Thailand & 42.69 & 23.79 & 0.824 & English \\
\hline Trinidad and Tobago & 45.97 & 32.90 & 0.176 & English \\
\hline United Kingdom & 100.91 & 68.79 & 1.195 & English \\
\hline United States & 100.00 & 100.00 & 0.823 & English \\
\hline Zimbabwe & 24.81 & 9.33 & 0.262 & English \\
\hline Average English & 61.13 & 36.37 & 0.59 & \\
\hline Argentina & 73.98 & 35.94 & 0.134 & French \\
\hline Belgium & 131.93 & 74.21 & 0.353 & French \\
\hline Bolivia & 35.58 & 9.13 & 0.009 & French \\
\hline Brazil & 66.25 & 23.93 & 0.241 & French \\
\hline Chile & 52.90 & 31.10 & 1.113 & French \\
\hline Colombia & 45.10 & 19.08 & 0.203 & French \\
\hline Cote d'Ivoire & 37.94 & 6.98 & 0.065 & French \\
\hline Ecuador & 42.80 & 13.11 & 0.144 & French \\
\hline Egypt, Arab Rep. & 29.04 & 12.78 & 0.105 & French \\
\hline France & 132.28 & 70.95 & 0.318 & French \\
\hline Greece & 92.04 & 43.80 & 0.141 & French \\
\hline Honduras & 33.63 & 7.47 & 0.049 & French \\
\hline Indonesia & 29.87 & 12.51 & 0.283 & French \\
\hline Iran, Islamic Rep. & 33.57 & 18.65 & 0.052 & French \\
\hline Italy & 96.79 & 70.92 & 0.180 & French \\
\hline Jordan & 39.50 & 14.09 & 0.693 & French \\
\hline Luxembourg & 129.82 & 121.02 & 1.708 & French \\
\hline Mauritius & 32.00 & 39.67 & 0.361 & French \\
\hline Mexico & 44.79 & 25.20 & 0.392 & French \\
\hline Morocco & 37.13 & 12.05 & 0.157 & French \\
\hline Netherlands & 130.20 & 73.87 & 0.812 & French \\
\hline Panama & 55.10 & 19.55 & 0.097 & French \\
\hline Paraguay & 35.43 & 18.77 & 0.011 & French \\
\hline Peru & 57.31 & 15.68 & 0.169 & French \\
\hline Philippines & 35.54 & 10.64 & 0.763 & French \\
\hline Portugal & 83.76 & 46.27 & 0.162 & French \\
\hline Spain & 93.13 & 57.33 & 0.316 & French \\
\hline Tunisia & 37.58 & 19.16 & 0.183 & French \\
\hline Turkey & 45.14 & 21.81 & 0.136 & French \\
\hline Uruguay & 64.97 & 30.94 & 0.010 & French \\
\hline Venezuela & 53.70 & 23.61 & 0.068 & French \\
\hline Average French & 61.57 & 32.27 & 0.30 & \\
\hline Austria & 140.95 & 74.33 & 0.137 & German \\
\hline Germany & 145.59 & 74.12 & 0.218 & German \\
\hline Japan & 183.49 & 82.33 & 0.723 & German \\
\hline Korea, Rep. & 80.09 & 48.57 & 0.419 & German \\
\hline Switzerland & 180.99 & 86.43 & 1.167 & German \\
\hline Taiwan, China & 87.09 & 51.41 & 0.854 & German \\
\hline Average German & 136.37 & 69.53 & 0.59 & \\
\hline Denmark & 149.29 & 82.88 & 0.322 & Scandinavian \\
\hline Finland & 136.69 & 66.38 & 0.331 & Scandinavian \\
\hline Iceland & 128.24 & 72.94 & 0.086 & Scandinavian \\
\hline Norway & 146.16 & 82.51 & 0.277 & Scandinavian \\
\hline Sweden & 133.13 & 73.27 & 0.672 & Scandinavian \\
\hline Average Scandinavian & 138.70 & 75.60 & 0.34 & \\
\hline Armenia & 15.41 & 7.97 & 0.001 & Socialist \\
\hline Bulgaria & 23.45 & 23.84 & 0.004 & Socialist \\
\hline China & 22.82 & 9.89 & 0.062 & Socialist \\
\hline Croatia & 59.70 & 24.19 & 0.030 & Socialist \\
\hline Czech Republic & 40.14 & 45.00 & 0.215 & Socialist \\
\hline Hungary & 51.15 & 30.60 & 0.046 & Socialist \\
\hline Lithuania & 26.89 & 21.62 & 0.015 & Socialist \\
\hline Poland & 45.70 & 25.83 & 0.014 & Socialist \\
\hline Romania & 33.26 & 16.85 & 0.004 & Socialist \\
\hline Russian Federation & 32.28 & 25.34 & 0.023 & Socialist \\
\hline Slovak Republic & 35.41 & 34.69 & 0.067 & Socialist \\
\hline Slovenia & 75.12 & 45.08 & 0.024 & Socialist \\
\hline Average Socialist & 38.44 & 25.91 & 0.04 & \\
\hline
\end{tabular}

